\title{
Modulation of Hair Growth Promoting Effect by Natural Products
}

\author{
Seyeon Park ${ }^{1}$ and Joomin Lee ${ }^{2, *(D)}$ \\ 1 Department of Applied Chemistry, Dongduk Women's University, Seoul 02748, Korea; \\ sypark21@dongduk.ac.kr \\ 2 Department of Food and Nutrition, Chosun University, Gwangju 61452, Korea \\ * Correspondence: joominlee@chosun.ac.kr; Tel.: +82-62-230-7722
}

Citation: Park, S.; Lee, J. Modulation of Hair Growth Promoting Effect by Natural Products. Pharmaceutics 2021, 13, 2163. https://doi.org/10.3390/ pharmaceutics 13122163

Academic Editor: Montse Mitjans Arnal

Received: 8 November 2021

Accepted: 10 December 2021

Published: 15 December 202

Publisher's Note: MDPI stays neutral with regard to jurisdictional claims in published maps and institutional affiliations.

Copyright: (c) 2021 by the authors. Licensee MDPI, Basel, Switzerland. This article is an open access article distributed under the terms and conditions of the Creative Commons Attribution (CC BY) license (https:// creativecommons.org/licenses/by/ $4.0 /)$.

\begin{abstract}
A large number of people suffer from alopecia or hair loss worldwide. Drug-based therapies using minoxidil and finasteride for the treatment of alopecia are available, but they have shown various side effects in patients. Thus, the use of new therapeutic approaches using bioactive products to reduce the risk of anti-hair-loss medications has been emphasized. Natural products have been used since ancient times and have been proven safe, with few side effects. Several studies have demonstrated the use of plants and their extracts to promote hair growth. Moreover, commercial products based on these natural ingredients have been developed for the treatment of alopecia. Several clinical, animal, and cell-based studies have been conducted to determine the anti-alopecia effects of plant-derived biochemicals. This review is a collective study of phytochemicals with antialopecia effects, focusing mainly on the mechanisms underlying their hair-growth-promoting effects.
\end{abstract}

Keywords: alopecia; natural product; hair growth

\section{Introduction}

Hair affects the impacts of thermoregulation, physical protection, and social interaction [1]. Hair disorders, which include alopecia, anagen effluvium, telogen effluvium, hirsutism, hypertrichosis, and miniaturization, negatively affect health [2]. Alopecia is defined as a decrease in hair density and can be considered a common symptom of several pathologies, such as inflammation and infection [3]. Alopecia can be a sign of a systemic disease, including thyroid dysfunction, systemic lupus erythematosus, trichotillomania, or infection [3]. Although alopecia is a non-life-threatening condition, it can affect the esthetics, social activities, and quality of life of individuals [4]. Hair growth is the result of the growth and differentiation of hair follicles (HFs) comprising dermal papilla cells (DPCs) and epithelial cells. The formation of HF involves four cycles: anagen (growth), catagen (regression), telogen (rest), and exogen (shedding). The hair cycle transition is controlled by several growth stimulatory or inhibitory factors [5]. Alopecia can be categorized into several classes. Androgenetic alopecia, the most common form of alopecia, is a male or female pattern hair loss that is characterized by a progressive loss of hair diameter, length, and pigmentation. It is caused by genetic factors and inadequate androgen signaling [6]. Androgenetic alopecia also worsens conditions such as drug side effects, acute stressors, and weight loss [6]. Alopecia areata is an autoimmune disorder (similar disorders include thyroid disease, celiac disease, vitiligo, and atopy) caused by lymphocytes that attack the bulb of HFs in the anagen phase [7]. This disease affects up to $2 \%$ of the population and commonly occurs during childhood or adolescence [7]. Patients with alopecia areata may experience sudden hair loss [8]. Telogen effluvium refers to the loss of telogen hair due to abnormal hair circulation, and generally 100-200 telogen hairs are lost every day [9]. The causes of acute telogen effluvium (in which hair loss lasts less than six months) includes systemic disease, drugs, fever, psychological/emotional stress, weight loss, childbirth, iron and vitamin D deficiency, inflammatory scalp disorders, interruption of oral contraceptives, 
and iron deficiency [10]. Primary cicatricial alopecia, known as scarring alopecia, encompasses hair loss disorders in which the hair follicle is irreversibly destroyed [11]. Secondary cicatricial alopecia occurs from irreversible loss of hair follicles due to thermal burns, metastatic cancer, trauma, or radiation [11]. To date, the US Food and Drug Administration (FDA)-approved non-surgical treatment alternatives for hair loss include drugs such as minoxidil and finasteride. Minoxidil is converted to minoxidil sulfate by sulfotransferase present in the scalp, which promotes the growth of hair follicular cells and reduces hair loss [12]. Finasteride is a $5 \alpha$-reductase inhibitor that blocks the conversion of testosterone to dihydrotestosterone (DHT), which causes androgenetic alopecia [13]. However, these drugs have side effects in patients. Thus, it is necessary to identify new, safe, and effective drugs to treat hair loss.

Recently, interest in hair loss prevention using natural products or their extracts has increased. Products currently marketed as using natural ingredients include those used to prevent hair loss in the form of hair tonics, hair growth promoters, hair conditioners, and hair cleansers [14]. Plants and their extracts contain multiple components, such as polyphenols, flavonoids, terpenoids, carotenoids, and fatty acids, which support the maintenance of HF health [15]. Plant-based formulations have the advantage of being easy to acquire from low-cost materials, and their non-toxic effects have been noted since ancient times. Although natural products are widely used to prevent hair loss, little is known about their exact mechanisms of action. The present study is a review of the molecular mechanisms underlying the hair-promoting effects of various herbs and their constituents.

\section{Biochemical Action of Herbs and Their Extracts}

Various phytochemicals and their active constituents have been shown to promote hair growth in vivo and in vitro. Table 1 provides an overview of bioactive components from plants. A summary of the potential mechanisms of action on hair growth using plants is presented in Figure 1 and Table 2.

Table 1. Bioactive components from plants with hair-growth-promoting therapeutic effects.

\begin{tabular}{|c|c|c|c|c|}
\hline Botanical Name & Parts Used & Bioactive Components & Type of Extract & Ref \\
\hline $\begin{array}{l}\text { Citrus limon L., Fragaria } \\
\text { ananassa L., Secale cereale L. }\end{array}$ & - & Sinapic acid & - & [16] \\
\hline Epimedium spp. & Leaves & Icariin & - & [17] \\
\hline Geranium sibiricum L. & Whole plant & Corilagin, gallic acid & Methanolic extract & [18] \\
\hline Olea europaea L. & $\begin{array}{l}\text { Unprocessed olive } \\
\text { fruit and leaves }\end{array}$ & Oleuropein & - & [19] \\
\hline $\begin{array}{c}\text { Camellia sinensis, Coffea ara } \\
\text { bica }\end{array}$ & - & Caffeine & - & [20] \\
\hline Carthamus tinctorius L. & Floret & Hydroxysafflor yellow A & Ethanolic extract & [21] \\
\hline Panax ginseng Mayer & Whole plant & $\begin{array}{l}\text { Linoleic acid, } \beta \text {-sitosterol, } \\
\text { bicyclo(10.1.0)tridec-1-ene }\end{array}$ & $\begin{array}{l}\text { Supercritical fluid } \\
\text { extraction system }\end{array}$ & [22] \\
\hline Hottuynia cordata Thunb. & - & Quercitrin & - & [23] \\
\hline Sophora flavescens Aiton & Roots & L-maackiain, medicarpin & Methanolic extract & [24] \\
\hline $\begin{array}{l}\text { Illicium anisatum } \text { L., Illicium } \\
\text { verum Hook. } \mathrm{f} .\end{array}$ & - & Shikimic acid & - & [25] \\
\hline $\begin{array}{l}\text { Hordeum vulgare L. var. } \\
\text { distichon Alefeld }\end{array}$ & Seed & Procyanidin B-3 & Aceton extract & [26] \\
\hline Panax ginseng Mayer & - & Ginsenoside Rb1 & - & [27] \\
\hline Nelumbinis semen & Whole plant & $\begin{array}{c}\text { Anthraquinone, flavonoids, tannin, } \\
\text { saponins }\end{array}$ & Ethanolic extract & [28] \\
\hline
\end{tabular}


Table 1. Cont.

\begin{tabular}{|c|c|c|c|c|}
\hline Botanical Name & Parts Used & Bioactive Components & Type of Extract & Ref \\
\hline Chamaecyparis obtusa & - & $\begin{array}{l}\alpha \text {-Terpinyl acetate, sabinene, isobornyl } \\
\text { acetate, limonene }\end{array}$ & Oil & [29] \\
\hline Polygonum multiflorum & Roots & $\begin{array}{l}\text { 2,3,5,4'-Tetrahydroxystilbene2-O- } \beta \text { - } \\
\text { D-glucoside, emodin }\end{array}$ & Ethanolic extract & [30] \\
\hline Alnus sibirica Fisch. ex Turcz & Whole plant & Oregonin & Ethanolic extract & [31] \\
\hline Malva verticillate & Seed & Myristoleic acid & Ethanolic extract & [32] \\
\hline Malva verticillate & Seed & Linoleic acid & Ethanolic extract & [33] \\
\hline Magnolia officinalis & - & Liposomal honokiol & - & {$[34]$} \\
\hline Angelica gigas Nakai & Roots & Decursin & Ethanolic extract & [35] \\
\hline Caesalpinia sappan $\mathrm{L}$. & - & 3-Deoxysappanchalcone & - & [36] \\
\hline Broussonetia papyrifera & Whole plant & $\begin{array}{l}\text { 7-hydroxycoumarin, protocatechuate } \\
\text { acid, ferulic acid, protocatechuic acid } \\
\text { and epicatechin }\end{array}$ & Ethanolic extract & [37] \\
\hline Panax ginseng Mayer & Whole plant & Linoleic acid, $\beta$-sitosterol & $\begin{array}{l}\text { Supercritical fluid } \\
\text { extraction system }\end{array}$ & [38] \\
\hline Thuja orientalis & Leaves & Kaempferol, isoquercetin & Hot water extract & [39] \\
\hline Ipomoea batatas L. & - & 3,4,5-tri-O-caffeoylquinic acid & - & {$[40]$} \\
\hline Ishige sinicola & Whole plant & Octaphlorethol A & Ethanolic extract & [41] \\
\hline Prunus mira Koehne & Nut oil & $\begin{array}{l}\alpha \text {-tocopherol, vitamin E } \beta \text {-sitosterol, } \\
\text { linoleic acid, oleic acid }\end{array}$ & Pressing the seeds & [42] \\
\hline Saussurea lappa Clarke & - & Costunolide & - & [43] \\
\hline Cornus officinalis & - & Morroniside & - & {$[44]$} \\
\hline Anemarrhena asphodeloides & - & Timosaponin BII & - & [45] \\
\hline Salvia plebeia R. Br. & Whole plant & $\begin{array}{l}\text { Flavonoids, monoterpenoids, } \\
\text { sesquiterpenoids, diterpenoids, } \\
\text { triterpenes, phenolic acids }\end{array}$ & Methanolic extract & [46] \\
\hline Undariopsis peterseniana & Whole plant & Apo-9'-fucoxanthinone & Ethanolic extract & [47] \\
\hline Pueraria thomsonii & Whole plant & Soyasaponin I, kaikasaponin III & Ethanolic extract & [48] \\
\hline Platycladus orientalis (L.) Franco & Leaves & $\begin{array}{l}\text { Myricitrin, isoquercitrin, quercitrin, } \\
\text { myricetin, afzelin, quercetin, } \\
\text { kaempferol, amentoflavone, } \\
\text { hinokiflavone }\end{array}$ & $\begin{array}{l}\text { Ethanolic extract, } \\
\text { aqueous extract }\end{array}$ & [49] \\
\hline Panax ginseng & Rhizome & Ginsenoside Ro & Ethanolic extract & [50] \\
\hline $\begin{array}{l}\text { Polygonum multiforum } \\
\text { Thunb. }\end{array}$ & Leaves & Physcion & - & [51] \\
\hline Rosmarinus officinalis & Leaves & 12-methoxycarnosic acid & Ethanolic extract & [52] \\
\hline Avicennia marina & Heartwood & Avicequinone $\mathrm{C}$ & Methanolic extract & [53] \\
\hline Ecklonia cava & Whole plant & Dieckol & $\begin{array}{l}\text { Enzymatic hydrolysis } \\
\text { reaction }\end{array}$ & [54] \\
\hline Camellia sinensis L. Ktze. & - & Epigallocatechin-3-Gallate & - & [55] \\
\hline Panax ginseng Mayer & Roots & Ginsenosides & Ethanolic extract & {$[56]$} \\
\hline Sabal serrulatum & - & Fatty acids, phytosterols & - & [57] \\
\hline
\end{tabular}




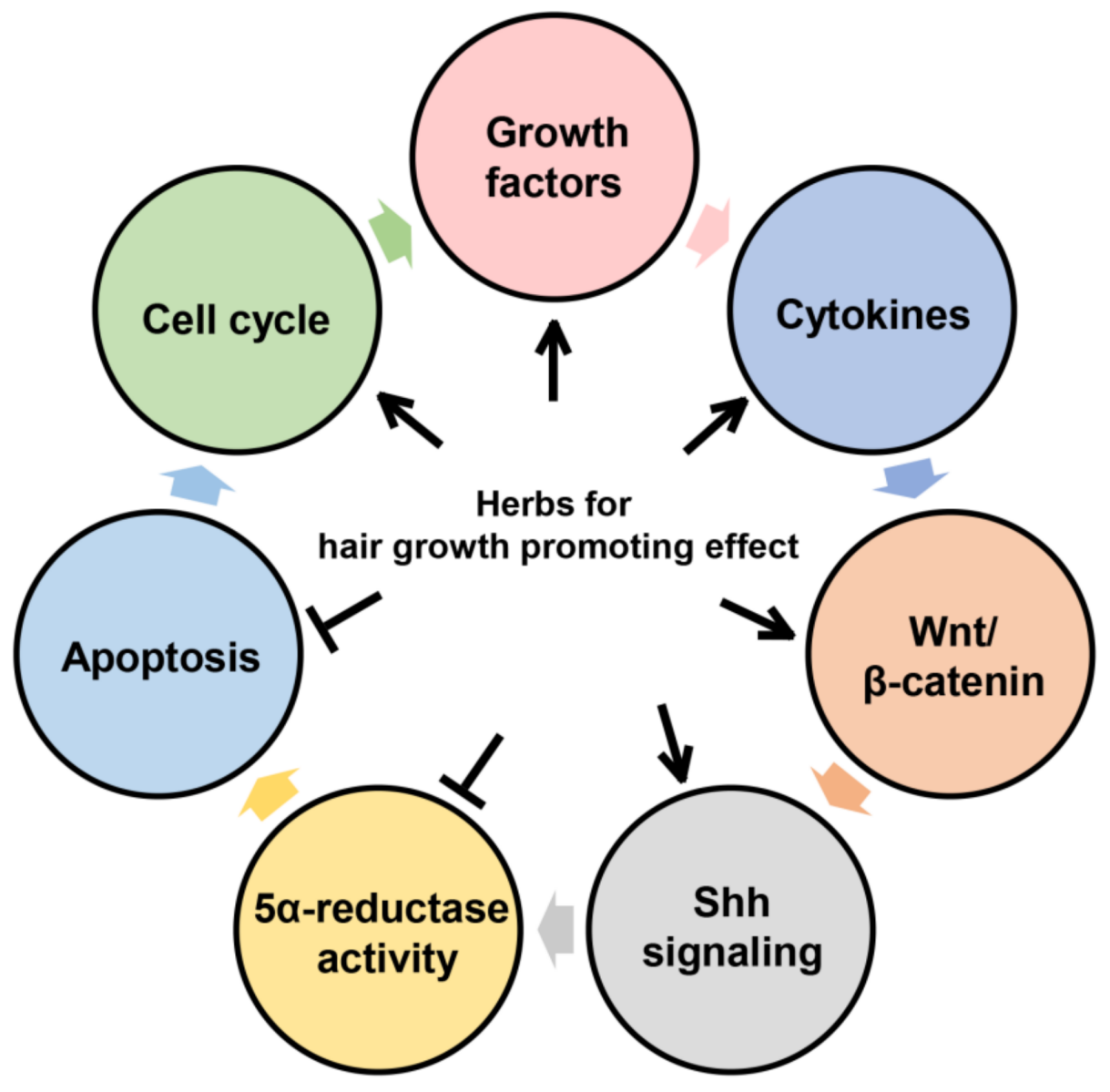

Figure 1. Interactions between herbs and their mechanisms for hair-growth-promoting efficacies.

\subsection{Growth Factors}

Numerous growth factors were expressed in the HFs. Fibroblast growth factor (FGF), vascular endothelial growth factor (VEGF), keratinocyte growth factor (KGF), insulin-like growth factor (IGF), epidermal growth factor (EGF), and hepatocyte growth factor (HGF) act as hair growth stimulators, and transforming growth factor- $\beta 1$ (TGF- $\beta 1$ ) is a hair growth suppressor [6]. VEGF is secreted by DPCs and is involved in hair growth through the formation of new blood vessels around follicles [58,59]. VEGF expression is decreased in HFs during alopecia compared to that in normal follicles [59]. IGF-1 signaling has been reported to influence HF development and tissue renewal [60]. IGF-1 prevents HFs from entering the catagen phase [61,62]. The FGF family consists of 22 members and regulates a variety of biological functions [63]. Basic FGF (FGF-2) and KGF-2 (FGF-10) stimulate HF growth [64]. KGF mediates growth, development, and differentiation of HF [6]. HGF is involved in the stimulation of mouse follicle growth and HF elongation in vitro and in vivo $[65,66]$. TGF- $\beta 1$ and its receptors are involved in the catagen phase of the hair cycle and promote tissue remodeling and apoptosis [67]. 
Table 2. Studies of hair-growth-promoting effects using natural products or their extracts.

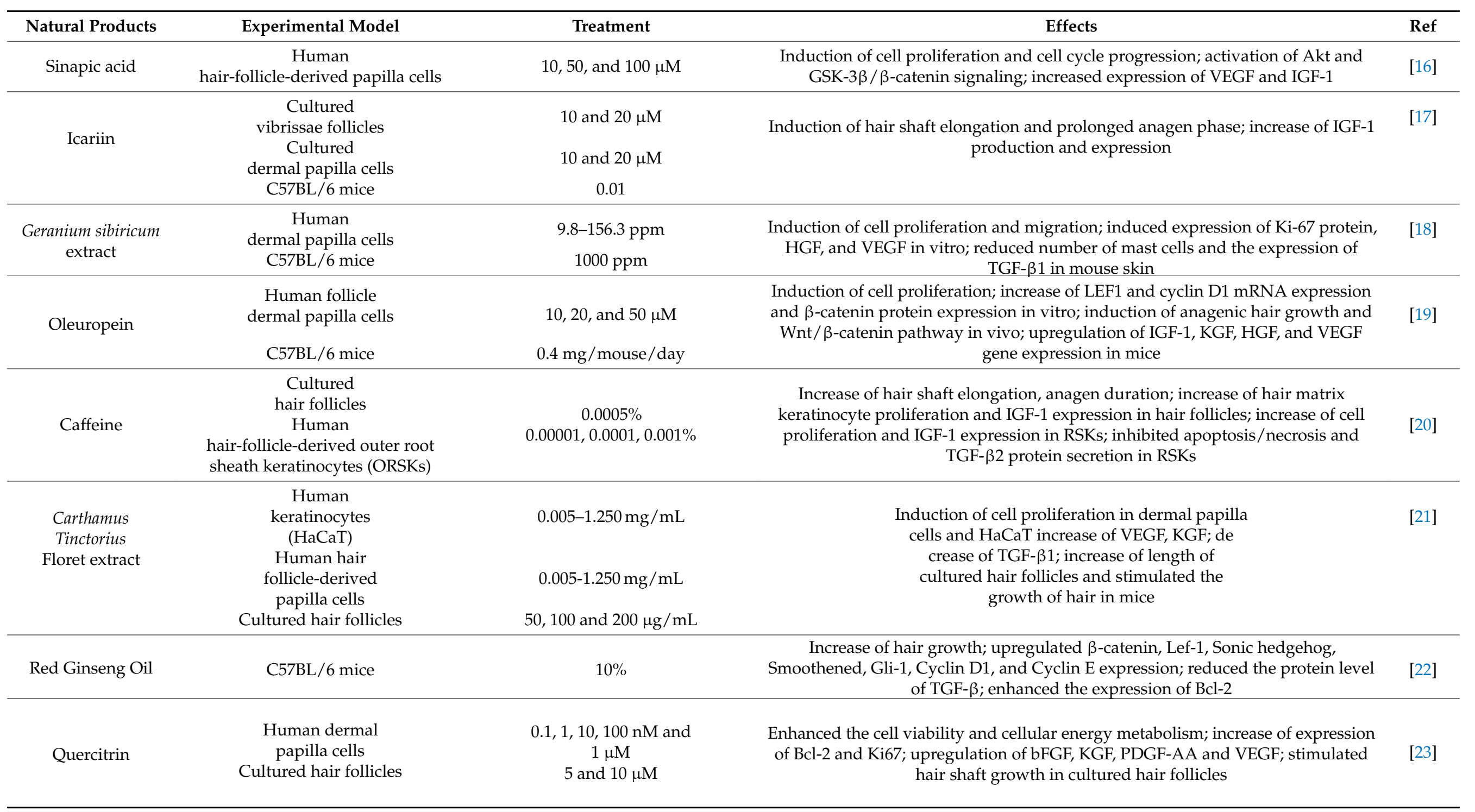


Table 2. Cont.

\begin{tabular}{|c|c|c|c|c|}
\hline Natural Products & Experimental Model & Treatment & Effects & Ref \\
\hline $\begin{array}{l}\text { Sophora } \\
\text { flavescens } \\
\text { extract }\end{array}$ & $\begin{array}{l}\text { Cultured } \\
\text { dermal papilla cells } \\
\text { Sprague-Dawley rats } \\
\text { C57BL/6 mice }\end{array}$ & $\begin{array}{l}10^{-6}, 10^{-5} \text { and } 10^{-4 \%} \\
0.001,0.01 \text { and } 0.01 \% \\
1 \%\end{array}$ & $\begin{array}{l}\text { Induction of hair growth in vivo; increase of IGF-1 and KGF in vitro; decrease of } \\
\text { 5a-reductase activity in vivo }\end{array}$ & [24] \\
\hline Shikimic acid & $\begin{array}{c}\text { Human follicle } \\
\text { dermal papilla cells } \\
\text { Human outer root sheath } \\
\text { keratinocytes } \\
\text { C57BL/6 mice } \\
\text { Cultured } \\
\text { hair follicles }\end{array}$ & $\begin{array}{l}0.1,1,10,100 \mu \mathrm{M} \text { and } 1 \mathrm{mM} \\
1 \text { and } 10 \mu \mathrm{M} \\
10 \text { and } 100 \mathrm{mM} \\
1 \text { and } 10 \mu \mathrm{M}\end{array}$ & $\begin{array}{l}\text { Induction of hair growth in vivo; increase of } \\
\text { Cell proliferation in hDPCs and hORSCs; en } \\
\text { hanced hair shaft elongation in cultured hair } \\
\text { follicles; increased c-myc, HGF, KGF, VEGF, } \\
\text { p38 MAPK and CREB }\end{array}$ & [25] \\
\hline Procyanidin B-3 & $\begin{array}{l}\text { Cultured hair epithelial cells from } \\
\text { C3H/HeNCrj mice } \\
\text { C3H mice }\end{array}$ & $\begin{array}{c}0.1-100 \mu \mathrm{g} / \mathrm{mL} \\
200 \mu \mathrm{L} / \text { day } / \text { mouse }\end{array}$ & $\begin{array}{l}\text { Increased hair-growing activity in vitro and anagen-inducing activity in vivo; } \\
\text { potential inhibitory effect of TGF- } \beta 1\end{array}$ & [26] \\
\hline Ginsenoside Rb1 & $\begin{array}{l}\text { Cultured mink hair follicles } \\
\text { Cultured dermal } \\
\text { papilla cells }\end{array}$ & $\begin{array}{l}5 \text { and } 10 \mu \mathrm{g} / \mathrm{mL} \\
\qquad 10 \mu \mathrm{g} / \mathrm{mL}\end{array}$ & $\begin{array}{l}\text { Increase of the growth of hair follicles; upregulated the expression levels of } \\
\text { VEGF-A and VEGF-R2, while attenuated the TGF- } \beta 1 \text { expression; activation of } \\
\text { PI3K/AKT/GSK-3 } \beta \text { signaling pathway in hair follicles and DPCs. }\end{array}$ & [27] \\
\hline $\begin{array}{l}\text { Nelumbinis Semen } \\
\text { extract }\end{array}$ & $\begin{array}{l}\text { Human follicle } \\
\text { dermal papilla cells } \\
\text { C57BL/6 mice }\end{array}$ & $\begin{array}{l}15.63-125 \mathrm{ppm} \\
1000 \mathrm{ppm}\end{array}$ & $\begin{array}{l}\text { Enhanced cell proliferation and migration; high } \\
\text { mRNA expression of VEGF and IGF-1; low TGF- } \\
\qquad \beta 1 \text { mRNA expression }\end{array}$ & [28] \\
\hline $\begin{array}{l}\text { Chamaecyparisobtusa } \\
\text { oil }\end{array}$ & C57BL/6 mice & $3 \%$ & $\begin{array}{l}\text { Increase of ALP and } \gamma \text {-GT activities in the skin tissue; increase of IGF-1 mRNA } \\
\text { expression; increase of VEGF and decrease of EGF expression in the skin tissue; } \\
\text { increase of SCF expression }\end{array}$ & [29] \\
\hline $\begin{array}{l}\text { Polygonum } \\
\text { multiflorum } \\
\text { extract }\end{array}$ & $\begin{array}{l}\text { Human follicle } \\
\text { dermal papilla cells } \\
\text { Cultured hair follicles }\end{array}$ & $\begin{array}{l}10 \text { and } 100 \mu \mathrm{g} / \mathrm{mL} \\
2,20, \text { and } 50 \mu \mathrm{g} / \mathrm{mL}\end{array}$ & $\begin{array}{l}\text { Increased cell viability and mitochondrial activity; increase of Bcl-2 and decrease of } \\
\text { BAD and DKK-1; increase of IGFBP2, PDGF and VEGF; prolonged the anagen of } \\
\text { human hair follicles }\end{array}$ & [30] \\
\hline $\begin{array}{l}\text { Alnus } \\
\text { sibirica Fisch. } \\
\text { ex Turcz }\end{array}$ & $\begin{array}{l}\text { Human follicle } \\
\text { dermal papilla cells }\end{array}$ & 22,66 and $200 \mu \mathrm{g} / \mathrm{mL}$ & $\begin{array}{l}\text { Inhibition of apoptosis; increased IGF-1 and decreased TGF- } \beta 1 \text { expression; } \\
\text { decreased DHT production }\end{array}$ & [31] \\
\hline $\begin{array}{l}\text { Malva verticillata } \\
\text { seed extracts }\end{array}$ & $\begin{array}{l}\text { Human follicle } \\
\text { dermal papilla cells }\end{array}$ & $10-100 \mu \mathrm{g} / \mathrm{mL}$ & $\begin{array}{l}\text { Increased Wnt reporter activity; increased } \beta \text {-catenin level; increased IGF-1, KGF, } \\
\text { VEGF and HGF }\end{array}$ & {$[32]$} \\
\hline
\end{tabular}


Table 2. Cont.

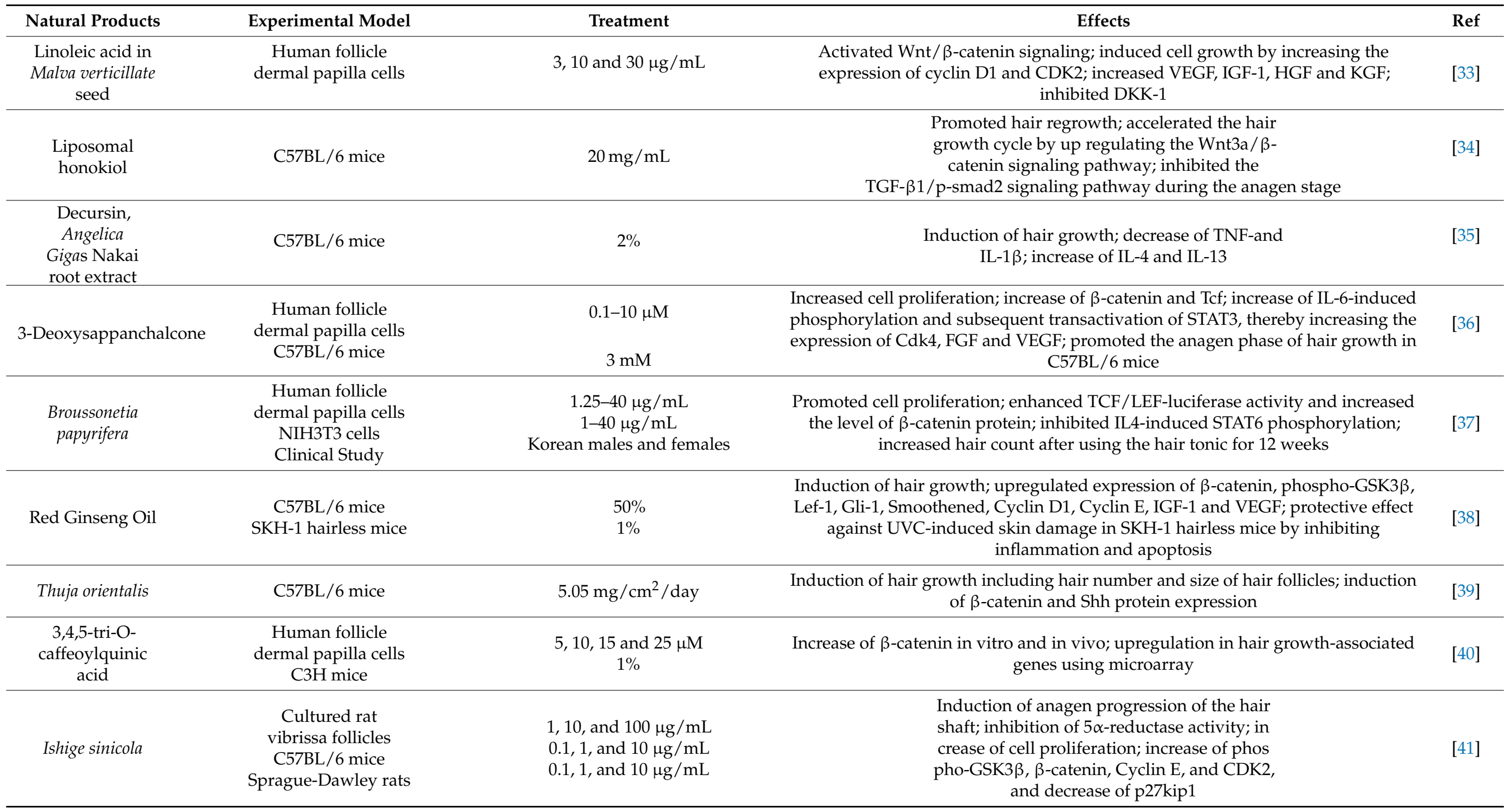


Table 2. Cont.

\begin{tabular}{|c|c|c|c|c|}
\hline Natural Products & Experimental Model & Treatment & Effects & Ref \\
\hline $\begin{array}{c}\text { Prunus } \\
\text { mira Koehne }\end{array}$ & $\begin{array}{l}\text { C57BL/6 mice } \\
\text { KM mice }\end{array}$ & $\begin{array}{c}15.06,30.13 \text {, and } 60.26 \mathrm{mg} / \mathrm{cm}^{2} / \text { day } \\
0.47-60.26 \mathrm{mg} / \mathrm{cm}^{2} / \text { day }\end{array}$ & Increase of hair growth; increase of Wnt $10 \mathrm{~b}, \beta$-catenin, and GSK- $3 \beta$ & [42] \\
\hline Costunolide & $\begin{array}{l}\text { Human follicle } \\
\text { dermal papilla cells } \\
\text { C57BL/6 mice }\end{array}$ & $\begin{array}{c}0.1,0.3,1, \text { and } 3 \mu \mathrm{M} \\
0.3 \mu \mathrm{M}\end{array}$ & $\begin{array}{l}\text { Increase of cell proliferation in vitro; inhibited } \\
\text { the 5a-reductase activity in hHFDPCs; in } \\
\text { creased the level of } \beta \text {-catenin and Gli1 and de } \\
\text { creased TGF- } \beta 1 \text {; increase of hair length in vivo }\end{array}$ & [43] \\
\hline Morroniside & $\begin{array}{l}\text { Cultured outer root sheath cells } \\
\text { C57BL } / 6 \text { mice }\end{array}$ & $\begin{array}{c}1 \text { and } 10 \mu \mathrm{M} \\
100 \mu \mathrm{M}\end{array}$ & $\begin{array}{c}\text { Enhanced outer root sheath cell proliferation } \\
\text { and migration in vitro; upregulation of } \\
\text { Wnt10b, } \beta \text {-catenin, and LEF1; accelerated the } \\
\text { onset of anagen and delayed hair follicle cat } \\
\text { agen }\end{array}$ & [44] \\
\hline Timosaponin BII & C57BL/6 mice & $0.5 \%$ & $\begin{array}{l}\text { Induced hair growth; increased expression of } \\
\qquad \beta \text {-catenin and Wnt } 10 \mathrm{~b}\end{array}$ & [45] \\
\hline $\begin{array}{l}\text { Salvia } \\
\text { plebeian } \\
\text { extract }\end{array}$ & $\begin{array}{l}\text { Human follicle } \\
\text { dermal papilla cells } \\
\text { C57BL/6 mice }\end{array}$ & $\begin{array}{c}\text { 7.8, 15.6, and } 31.3 \mu \mathrm{g} / \mathrm{mL} \\
1,000 \mu \mathrm{g} / \mathrm{mL}\end{array}$ & $\begin{array}{l}\text { Increased cell proliferation; increased HGF } \\
\text { and decreased TGF- } \beta 1 \text { and SMAD } 2 / 3 \text {; inhibi } \\
\text { tion of apoptosis by increasing the Bcl-2/Bax } \\
\text { ratio; enhanced hair growth in mice }\end{array}$ & [46] \\
\hline $\begin{array}{l}\text { Undariopsis } \\
\text { peterseniana }\end{array}$ & $\begin{array}{l}\text { C57BL/6 mice } \\
\text { Cultured rat } \\
\text { vibrissa follicles } \\
\text { Sprague-Dawley rats } \\
\text { NIH3T3 fibroblasts } \\
\text { Dermal papilla cells }\end{array}$ & $\begin{array}{c}0.1,1 \text {, and } 10 \mu \mathrm{g} / \mathrm{mL} \\
1,10 \text {, and } 100 \mu \mathrm{g} / \mathrm{mL} \\
0.1,1,10 \text {, and } 100 \mu \mathrm{g} / \mathrm{mL} \\
0.1,1,10 \text {, and } 100 \mu \mathrm{g} / \mathrm{mL} \\
0.1,1 \text {, and } 10 \mu \mathrm{g} / \mathrm{mL}\end{array}$ & $\begin{array}{l}\text { Increase of the hair-fiber lengths and anagen } \\
\text { initiation in vivo; decreased } 5 \alpha \text {-reductase ac } \\
\text { tivity and increased cell proliferation in vitro; } \\
\text { increased the levels of Cyclin D1, phos } \\
\text { pho(ser780)-pRB, Cyclin E, phospho-CDK2, } \\
\text { and CDK2; increase of phosphorylation of } \\
\text { ERK and the levels of Wnt/ } \beta \text {-catenin signaling } \\
\text { proteins }\end{array}$ & [47] \\
\hline Puerariae Flos & $\begin{array}{l}\text { Wistar/ST rats } \\
\text { C57BL/6NCrSlc mice } \\
\text { C3H/He mice }\end{array}$ & $\begin{array}{l}50,200, \text { and } 500 \mu \mathrm{g} / \mathrm{mL} \\
2 \text { and } 5 \mathrm{mg} / \mathrm{mouse} / \text { day } \\
2 \text { and } 5 \mathrm{mg} / \mathrm{mouse} / \text { day }\end{array}$ & $\begin{array}{l}\text { Increase of hair re-growth effect in testos } \\
\text { terone-treated C57BL/6NCrSlc and C3H/He } \\
\text { mice; inhibitory activity of against testos } \\
\text { terone 5a-reductase }\end{array}$ & [48] \\
\hline $\begin{array}{l}\text { Cacumen } \\
\text { platycladi }\end{array}$ & $\begin{array}{c}\text { Sprague-Dawley rats } \\
\text { C57BL/6NCrSlc(C57) mice }\end{array}$ & $\begin{array}{c}0.02-2.5 \mu \mathrm{mol} / \mathrm{L} \\
2 \text { and } 5 \mathrm{mg} / \mathrm{mouse} / \text { day }\end{array}$ & Increase of hair growth; increase of Wnt $10 \mathrm{~b}, \beta$-catenin, and GSK- $3 \beta$ & [49] \\
\hline
\end{tabular}


Table 2. Cont.

\begin{tabular}{|c|c|c|c|c|}
\hline Natural Products & Experimental Model & Treatment & Effects & Ref \\
\hline $\begin{array}{l}\text { Ginseng } \\
\text { rhizome, } \\
\text { Ginsenoside Ro }\end{array}$ & $\begin{array}{l}\text { Wistar rats } \\
\text { C57BL/6 mice }\end{array}$ & $\begin{array}{c}\text { Ginseng rhizome } \\
(200,500, \text { and } 1,000 \\
\mu \mathrm{g} / \mathrm{mL}) \\
\text { Ginseng rhizomes } \\
(2 \mathrm{mg} / \mathrm{mouse}), \text { and } \\
\text { ginsenoside Ro } \\
(0.2 \mathrm{mg} / \mathrm{mouse}) \\
\end{array}$ & $\begin{array}{l}\text { Induced hair re-growth in vivo; inhibitory } \\
\text { effects against } 5 \alpha \mathrm{R}\end{array}$ & [50] \\
\hline Physcion & Sprague-Dawley ratsC57BL/6 mice & 12.5-100 $\mu \mathrm{M} 5 \mathrm{mg} / \mathrm{mouse} /$ day & $\begin{array}{l}\text { Inhibited the 5a-reductase activity; hair } \\
\text {-growth-promoting activity }\end{array}$ & [51] \\
\hline $\begin{array}{l}\text { Rosmarinus } \\
\text { officinalis } \\
\text { leaf extract }\end{array}$ & $\begin{array}{l}\text { Wistar rats } \\
\text { C3H/He mice } \\
\text { C57BL/6 mice } \\
\text { LNCaP cells }\end{array}$ & $\begin{array}{c}50,200, \text { and } 500 \mu \mathrm{g} / \mathrm{mL} \\
2 \mathrm{mg} / \mathrm{mouse} / \text { day } \\
2 \mathrm{mg} / \mathrm{mouse} / \text { day } \\
1-5 \mu \mathrm{M}\end{array}$ & $\begin{array}{l}\text { Improved hair regrowth in C57BL/6NCrSlc } \\
\text { mice; increased hair growth in C3H/He mice } \\
\text { that had their dorsal areas shaved; decreased } \\
\text { 5a-reductase activity; inhibited androgen-de } \\
\text { pendent proliferation of LNCaP cells }\end{array}$ & [52] \\
\hline Avicequinone $\mathrm{C}$ & Human hair dermal papilla cells & 5 and $10 \mu \mathrm{g} / \mathrm{mL}$ & Decreased 5a-reductase activity & [53] \\
\hline $\begin{array}{l}\text { Ecklonia cava } \\
\text { enzymatic } \\
\text { extract, dieckol }\end{array}$ & $\begin{array}{c}\text { Cultured rat } \\
\text { vibrissa follicles } \\
\text { Sprague-Dawley rats } \\
\text { C57BL/6 miceRat vibrissa, } \\
\text { immortalized dermal papilla cell, } \\
\text { NIH3T3 cells }\end{array}$ & $\begin{array}{c}0.01-10 \mu \mathrm{g} / \mathrm{mL} \\
0.5 \% \\
0.5 \% \\
0.001-10 \mu \mathrm{g} / \mathrm{mL} \\
0.05 \text { and } 10 \mu \mathrm{g} / \mathrm{mL}\end{array}$ & $\begin{array}{l}\text { Increased hair-fiber length and anagen pro } \\
\text { gression of the hair-shaf after E. cava enzy } \\
\text { matic extract; decreased 5a-reductase activity } \\
\text { in the presence of dieckol }\end{array}$ & [54] \\
\hline $\begin{array}{l}\text { Epigallocatechin-3- } \\
\text { Gallate }\end{array}$ & $\begin{array}{c}\text { Cultured mink } \\
\text { hair follicles } \\
\text { Cultured dermal } \\
\text { papilla cells } \\
\text { Cultured outer root sheath cells }\end{array}$ & $\begin{array}{c}0.1-5 \mu \mathrm{M} \\
0.25-4 \mu \mathrm{M} \\
0.25-4 \mu \mathrm{M}\end{array}$ & $\begin{array}{l}\text { Promoted hair follicle growth in DPCs and } \\
\text { ORSCs; activated Shh and Akt signaling; in } \\
\text { creased the expression of cyclin D1 and cyclin } \\
\text { E1 }\end{array}$ & [55] \\
\hline $\begin{array}{c}\text { Panax } \\
\text { ginseng extract }\end{array}$ & $\begin{array}{l}\text { Cultured outer root sheath } \\
\text { keratinocytes }\end{array}$ & $\begin{array}{l}20 \mathrm{ppm} \\
20 \mathrm{ppm}\end{array}$ & $\begin{array}{l}\text { Increased proliferation and inhibited apopto } \\
\text { sis in ORS keratinocytes; abrogated DKK-1-in } \\
\text { duced growth inhibition of cultured HFs ex } \\
\text { vivo }\end{array}$ & [56] \\
\hline $\begin{array}{l}\text { Serenoa repens } \\
\text { extracts }\end{array}$ & $\begin{array}{l}\text { Human keratinocyte cells } \\
\text { C57BL/6 mice }\end{array}$ & $\begin{array}{l}1,5,25, \text { and } 100 \mu \mathrm{g} / \mathrm{mL} \\
50 \%\end{array}$ & $\begin{array}{l}\text { Increased cell viabilities; stimulated hair folli } \\
\text { cle growth; decreased inflammatory response; } \\
\text { decreased TGF- } \beta 2 \text { and cleaved caspase- } 3 \text { ex } \\
\text { pression of hair loss mouse; inhibited apoptosis }\end{array}$ & [57] \\
\hline
\end{tabular}


Sinapic acid exhibits various biological activities, including antioxidant, anti-inflammatory, anticancer, anti-hyperglycemic, and neuroprotective effects [68-73]. Sinapic acid treatment has been reported to increase VEGF and IGF-1 expression and increase the proliferation of human HF-derived dermal papilla cells (hHFDPCs) [16]. Icariin is a bioactive compound from Epimedium brevicornum Maxim extract, which possesses testosterone mimetic properties and anti-osteoporotic and antidepressant-like effects [74-76]. Treatment with icariin increased IGF-1 secretion in vibrissae follicles and upregulated IGF-1 mRNA and protein levels in DPCs [17]. Geranium sibiricum L., belonging to the family Geraniaceae, has been used globally as an antioxidant and anti-inflammatory substance [77-79]. Geranium sibiricum extract increased HGF and VEGF expression, and decreased TGF- $\beta 1$ expression in vitro and in vivo [18]. Oleuropein, an olive constituent, is a phenolic glycoside that possesses several pharmacological properties, including antioxidant, antimicrobial, anticancer, cardioprotective, and neuroprotective effects [80-82]. Topical administration of oleuropein (0.4 mg/day) significantly upregulated IGF-1, KGF, HGF, and VEGF mRNA expression in mouse skin tissue compared with control mice [19]. Caffeine is a well-known stimulant that is widely consumed in common beverages [83]. It acts as a phosphodiesterase inhibitor and possesses biological activities, including antioxidant and cancer preventive effects [83-86]. Treatment with caffeine $(0.001 \%)$ and testosterone $(5 \mu \mathrm{g} / \mathrm{mL})$ significantly increased IGF-1 expression but decreased TGF- $\beta 2$ expression in human outer sheath keratinocytes [20]. Carthamus tinctorius L., known as Safflower, has been used in various medical conditions $[87,88]$. Carthamus tinctorius L. extract (CTE) decreased $5 \alpha$-reductase activity and promoted hair growth in mice [89]. CTE increased VEGF and KGF mRNA expression and decreased TGF- $\beta 1$ expression in vitro [21]. Red ginseng oil (RGO) extracted from red ginseng possesses antioxidant [90] and anti-inflammatory [91,92] effects, and its major constituents include linoleic acid (LA), $\beta$-sitosterol (SITOS), and bicyclo(10.1.0)tridec1-ene (BICYCLO) [93]. Truong et al., revealed that RGO (10\%) exhibited hair regeneration capacity in a testosterone-induced androgenic alopecia C57BL/6 mouse model [22]. RGO and its main compounds decreased the expression of TGF- $\beta 1$ compared with testosterone treatment [22]. Quercitrin (quercetin-3-O-rhamnoside) is a flavonoid found in various plants and has been shown to protect against cisplatin-induced hair damage [94]. Quercitrin treatment resulted in an increase in bFGF, KGF, platelet-derived growth factor (PDGF)-AA, and VEGF mRNA and protein levels in hDPCs [23]. Sophora flavescens possesses various pharmacological properties, including anti-inflammatory, anti-arthritic, and antioxidant effects $[95,96]$. It has been demonstrated that Sophora flavescens extract promoted hair growth by inducing mRNA expression of IGF-1 and KGF in cultured DP cells [24]. Shikimic acid is commercially used in cosmetics and has been shown to possess antibacterial, anti-inflammatory, antifungal, anti-aging, and whitening effects [97]. A recent study revealed that shikimic acid upregulated the mRNA expression of HGF, KGF, and VEGF in hDPCs [25]. Procyanidin (PC)-B3 is a procyanidin dimer that has been studied for its hair-growth-promoting effect $[98,99]$. The study showed increased hair-growing activity in vitro and anagen-inducing activity in vivo, as well as a potential inhibitory effect of TGF- $\beta 1$ [26]. Ginsenosides present in Ginseng Radix et Rhizoma are $\mathrm{Rb} 1, \mathrm{Rb} 2, \mathrm{Rb} 3, \mathrm{Rd}, \mathrm{Re}, \mathrm{Rg} 1, \mathrm{Rg} 3$, and $\mathrm{Rh} 2$, and ginsenoside $\mathrm{Rb} 1$ is one of the active compounds present in ginseng [100]. Studies have reported the hair-promoting effects of ginseng extract and ginsenosides in vitro and in vivo [100]. Ginsenoside Rb1 treatment induced VEGF-A and VEGF receptor 2 and attenuated TGF- $\beta 1$ expression [27]. Nelumbinis Semen (NS) is a widely used functional food that contains nutritional compounds with therapeutic benefits [101,102]. NS improved oxidative stress on the scalp of hair loss patients due to its high content of total polyphenols and flavonoids [103]. Park et al. also showed that NS extract possessed a strong antioxidant capacity and may reduce the oxidative damage that causes hair loss [28]. NS-extract-treated mice showed increased VEGF and IGF-1 mRNA expression [28]. However, TGF- $\beta 1$ mRNA expression was decreased after NS extract treatment compared to that after dimethyl sulfoxide (DMSO) treatment [28]. Chamaecyparis obtusa (CO), belonging to the family Cupressaceae, has alpha-terpinyl acetate, sabinene, isobornyl acetate, and limonene as major constituents [104]. An essential oil from 
CO has shown anti-inflammatory and antimicrobial activities in previous studies [104-107]. In the CO-treated mice group, IGF-1 mRNA expression was increased compared with that in the group treated with $3 \%$ minoxidil for 4 weeks. VEGF expression was also upregulated in the skin of mice after CO treatment [29]. Polygonum multiflorum (PM) has been used in Chinese medical practices [108] and reported to have various actions, including antioxidant [109], anti-human-immunodeficiency-virus (HIV) [110], neuroprotective [111,112], and hepatoprotective effects [113]. 2,3,5,4-Tetrahydroxystilbene-2-O-D-glucoside (TSG), a major component of PM, induces new hair growth in C57BL/6J mice [113]. Additionally, Shin et al., observed that PM extract $(20 \mu \mathrm{g} / \mathrm{mL})$ increased IGFBP2, PDGF, and VEGF expression in cultured hDPCs [30]. Alnus sibirica Fisch. ex Turcz (AS), belonging to the family Betulaceae, is rich in flavonoids [114], tannins [115,116], and diarylheptanoids [117]. AS or oregonin (active substance in AS) treatment increased IGF-1 levels and decreased TGF- $\beta 1$ levels in $\mathrm{H}_{2} \mathrm{O}_{2}$-induced stressed hDPCs [31]. Malva verticillate (MV) is an edible plant widely used in East Asia [118]. MV is a rich source of phenolic compounds that possess antioxidants [119], anti-complementary, hypoglycemic [120], and antidiabetic effects by activating AMP-activated protein kinase [121]. MV seed extract treatment upregulated the mRNA expression of growth factors, including IGF-1, KGF, VEGF, and HGF [32]. In another study, LA in MV seeds also elevated IGF-1, KGF, VEGF, and HGF mRNA expression in cultured hDPCs [33]. Liposomal honokiol is a natural extract from Magnolia officinalis [122,123] and mainly possesses anticancer effects [124,125]. Li et al. demonstrated that it has a hair-promoting effect, including increased thickness of the dermis and the number of HF in C57BL/6N mice [34]. Liposomal honokiol treatment inhibited TGF- $\beta 1$ protein expression and phosphorylated SMAD2 expression in the outer root sheath (ORS), as determined using immunohistochemistry analysis [34].

\subsection{Cytokines}

Cytokines such as interleukin (IL)-1 $\alpha$, IL-1 $\beta$, tumor necrosis factor- $\alpha$ (TNF- $\alpha$ ), interferon$\gamma($ IFN- $\gamma)$, IL-2, IL-4, and IL-5 can influence the hair cycle [126]. IL- $1 \alpha$, IL-1 $\beta$, and TNF- $\alpha$ are potent inducers of hair loss $[127,128]$. These cytokines exhibit similar patterns in alopecia areata, which involves abnormal keratinization of the hair matrix [129]. Overexpression of IL-l $\alpha$ in transgenic mice led to the development of inflammatory skin diseases, such as hair loss [130]. C57BL/ 6 mice overexpressing TNF- $\alpha$, IL- $1 \beta$, and IFN- $\gamma$ promote keratinocyte apoptosis associated with hair loss [131]. Clinical data revealed elevated serum levels of IL-4 in patients with localized alopecia areata [132]. Angelica gigas Nakai (AGN) has been extensively studied as a medicinal plant [133]. In particular, the roots of AGN showed antinociceptive activity in pain models [134], and neuroprotective [135] and beneficial effects in treating ischemia [136]. A recent study demonstrated that treatment with decursin $(0.15 \%)$, a major component isolated from AGN root, or AGN root extract $(2 \%)$ for 17 days stimulated hair growth in vivo [35]. These treatments reduced the protein levels of pro-inflammatory cytokines (TNF- $\alpha$ and IL-1 $\beta$ ) and increased anti-inflammatory cytokines (IL-4 and IL-13) in the dorsal skin of mice [35]. 3-Deoxysappanchalcone (DSC) is a biologically active compound from Caesalpinia sappan L., which has been suggested to have anti-inflammatory, anticancer, and anti-allergic effects [137-139]. 3-DSC treatment (0.1-3 $\mu \mathrm{M})$ increased IL-6-mediated signal transducer and activator of transcription (STAT) 3 expression in hDPCs [36]. 3-DSC also inhibits the phosphorylation of STAT6 mediated by IL-4 [36]. Another study reported that subjects with androgenic alopecia treated with shampoo containing Inula helenium and Caesalpinia Sappan extract (3-DSC) showed increased hair density and hair count [140]. Broussonetia papyrifera (BP), also known as paper mulberry, is a medicinal herb that utilizes leaves, fruits, and bark [141]. The polysaccharide extract from the fruits of BP showed antioxidant and antibacterial activities [142]. The BP root extract contains flavonoids, which results in inhibitory effects on nitric oxide, inducible nitric oxide synthase, TNF- $\alpha$, and IL-6 [143]. Treatment with BP eliminated IL-4-induced STAT6 phosphorylation in hDPCs [37]. 


\subsection{Wnt $/ \beta$-Catenin}

Wnt $/ \beta$-catenin signaling is broadly utilized and plays a crucial role in HF morphogenesis [144]. In canonical Wnt/ $\beta$-catenin signaling, Wnt proteins bind to Frizzled (FZD) receptors and low-density lipoprotein receptor-related protein $5 / 6$ (LRP5/6) co-receptors. Once activated, the $\beta$-catenin complex with APC and Axin is phosphorylated by casein kinase I $\alpha(C K I \alpha)$ and glycogen synthase kinase- $3 \beta$ (GSK-3 $\beta)$. Therefore, $\beta$-catenin accumulates in the cytoplasm and binds to the transcription factor T-cell factor/lymphoid enhancing factor (TCF/LEF) in the nucleus [145]. The study reported that Wnt/ $\beta$-catenin activation promotes hair regeneration by inhibiting GSK-3 $\beta$ in hDPCs [146]. Sinapic acid treatment increased the protein level of $\beta$-catenin by upregulating phosphorylated GSK-3 $\beta$ and Akt [16]. Oleuropein elevated nuclear $\beta$-catenin protein expression and increased LEF1 and cyclin D1 mRNA expression in DPCs [19]. Oleuropein administration increased the mRNA levels of Wnt10B, LRP5, and FZDR1, and the protein level of $\beta$-catenin in mice compared to minoxidil-treated C57BL/6 mice [19]. RGO remarkably increased the protein expression of $\beta$-catenin and LEF1 induced by testosterone and RGO co-treatment in dorsal skin tissues compared to treatment with testosterone alone [22]. RGO also enhanced $\beta$-catenin and phosphorylated GSK-3 $\beta$ protein expression in C57BL/ 6 mouse skin compared to that in the minoxidil-treated group [38]. Thuja orientalis (TO) is used to treat dermatitis, gout, and chronic tracheitis [147]. TO $\left(5.05 \mathrm{mg} / \mathrm{cm}^{2} /\right.$ day $)$ administration promoted hair growth and the early anagen phase, and prolonged the mature anagen phase in mice [39]. Immunohistochemical analysis showed increased $\beta$-catenin expression after TO treatment [39]. 3,4,5-Tri-O-caffeoylquinic acid (TCQA) is a caffeoylquinic acid derivative that acts as a neuroprotective agent and protects against amyloid- $\beta(A \beta)$-induced cell death $[148,149]$. Topical treatment with $1 \%$ TCQA prolonged anagen phase induction in $\mathrm{C} 3 \mathrm{H}$ mice for 30 days [40]. It was also confirmed that $\beta$-catenin expression increased in the skin of TCQA-treated mice and HFDPCs [40]. Gene expression profile data revealed an increase in the expression of the canonical Wnt-associated genes, Ctnnb1, Wls, Wnt2b, and Wnt4 after TCQA treatment [40]. Ishige sinicola (IS) is a brown alga that exhibits various activities, including osteoblastic bone formation [150] and anti-inflammatory effects [151]. IS treatment for 3 weeks increased hair-fiber length in rat vibrissa follicles and induced anagen progression of the hair shaft [41]. Protein expression of $\beta$-catenin and phosphorylation of GSK3 $\beta$ were increased after treatment with IS in cultured DPCs [41]. Prunus mira Koehne (PK) is a wild peach species that contains various nutrients and fatty acids [152]. Zhou et al., showed the hair-promoting effect of nut oil from PK [42]. They demonstrated that nut oil from PK increased hair length in mice and upregulated Wnt10B, $\beta$-catenin, and GSK-3 $\beta$ expression in mice [42]. Costunolide, a constituent of Saussurea lappa, has been used as an antioxidant, anti-inflammatory, and anticancer agent [153-155]. Costunolide increased cell proliferation and $\beta$-catenin expression in hHFDPCs [43]. Morroniside is the main component of Cornus officinalis and possesses neuroprotective, anti-apoptotic, and antioxidant effects [156-159]. Morroniside increased Wnt/ $\beta$-catenin signaling by upregulating Wnt10B, $\beta$-catenin, and LEF1 in cultured human ORS cells [44]. In a mouse model, morroniside promoted the anagen phase and delayed the catagen phase of HF, which was partly related to an increase in $\beta$-catenin expression [44]. 3-DSC inhibited the phosphorylation of $\beta$-catenin protein but promoted the transcriptional activity of TCF/LEF [36]. Timosaponin BII extracted from Anemarrhena asphodeloides rhizome is known to have antioxidant [160], anti-inflammatory [161,162], and anticancer [163] properties. A clinical study showed that application of timosaponin BII ( $0.5 \%)$ containing scalp care solution for 28 days resulted in improvement in hair and scalp conditions, particularly hair luster, scalp hydration, hair fall number, and scalp redness level [164]. A recent study showed that timosaponin BII (0.5\%) increased the hair regrowth area and HF number in mice [45]. Moreover, timosaponin BII treatment was shown to upregulate $\beta$-catenin and Wnt10B expression in the dorsal skin of mice [45]. The application of $20 \mathrm{mg} / \mathrm{mL}$ liposomal honokiol also increased Wnt3a and $\beta$-catenin expression [34]. Malva verticillata (MV) is a traditional herb native to Mongolia that contains flavan-3-ols, flavonoids, and 
fatty acids [119]. MV is a therapeutic candidate for diabetes [121], bone disease [165], and cancer [166]. MV leaves, stems, and seeds have been shown to be a rich source of phenolic compounds. Microbial fermentation has been used to increase the extraction yield of bioactive compounds from natural products [167]. Bacillus subtilis fermentation of MV leaves exhibited an antioxidant and osteogenic effect [168]. The seeds of MV (50 $\mu \mathrm{g} / \mathrm{mL})$ activated $\beta$-catenin protein expression in cultured DPCs [32]. Myristoleic acid, an active compound of MV, upregulates Wnt reporter activity [32]. Another study showed that LA in MV seeds increased cell proliferation and phosphorylation of GSK-3 and $\beta$-catenin in DPCs [33]. Salvia plebeia (SP) belongs to the family Labiaceae and is used for its antioxidant [169], anti-inflammatory [170,171], and anti-influenza [172] effects. It is reported to contain flavonoids, phenolic acids, and other nutrients [169]. SP extract enhanced the proliferation of hHFDPC and increased the TCF/LEF-luciferase activity as well as the level of $\beta$-catenin protein expression [46]. The use of hair tonics, including Broussonetia papyrifera (BP) extract, showed an increase in total hair count for 12 weeks in a clinical study. In addition, BP treatment increased TCF/LEF-luciferase activity and $\beta$-catenin protein levels in vitro [37]. Undariopsis peterseniana (UP), an edible brown seaweed, is a rich source of nutrients and acts as an antioxidant and anti-inflammatory agent [173-176]. UP extract was shown to induce hair growth in ex vivo organ cultures [47]. UP extract upregulated the phosphorylation levels of $\beta$-catenin and GSK- $3 \beta$ compared with the control in DPCs [47].

\section{4. $5 \alpha$-Reductase Inhibitory Effect}

Testosterone is converted to DHT by $5 \alpha$-reductase, which is known to cause androgenic alopecia [177]. Androgenic alopecia affects over $50 \%$ of men over the age of 50 [178], compared to only $25 \%$ of women by the age of 49 and $41 \%$ of women by the age of 69 years [179]. Finasteride, a $5 \alpha$-reductase inhibitor, has shown improvement in androgenic alopecia in clinical trials [13]. However, the use of 5- $\alpha$ reductase inhibitors has revealed that it has sexual and reproductive side effects [180]. DHT binds to androgen receptors in DPCs, leading to the onset of the telogen phase [177]. Sophora flavescens or Undariopsis peterseniana treatment showed potent $5 \alpha$-reductase inhibitory effects [24,47]. Octaphlorethol A, a constituent of Ishige sinicola, inhibited $5 \alpha$-reductase activity compared to that of finasteride [41]. Costunolide treatment downregulated testosterone-induced $5 \alpha$ reductase mRNA expression in hDPCs [43]. Puerariae Flos (PF) has been used as a medicinal herb for its antioxidant, antidiabetic, and protective effects against ethanol-induced injury [181-183]. PF extract showed inhibitory effects on $5 \alpha$-reductase and hair-growthpromoting effects in mice [48]. Cacumen platycladi (CP) is a Chinese medicine containing organic acids, flavonoids, and phenylpropanoids [184]. Treatment with CP decreased DHT levels and $5 \alpha$-reductase expression while promoting hair growth in vivo [49]. Another study showed that $\mathrm{CP}$ volatile oil treatment increased the proliferation of hDPCs and shortened the time of hair regrowth [185]. Ginseng rhizomes have been used in medical remedies $[186,187]$. Ginsenoside Ro, a major ginsenoside constituent in the ginseng rhizome, has anti-inflammatory [188,189], antioxidant [190], and anti-obesity [191] effects. Murata et al., revealed that red ginseng rhizome extract, ginsenoside Ro, and ginsenoside Rg3 showed inhibitory effects on $5 \alpha$-reductase activity [50]. The study also showed that topical administration of red ginseng rhizomes $(2 \mathrm{mg} / \mathrm{mouse})$ and ginsenoside Ro $(0.2 \mathrm{mg} / \mathrm{mouse})$ induced hair regrowth in testosterone-treated mice [50]. Physcion, a component of Polygonum multiforum (PM), has anti-inflammatory, antioxidant, and anticancer effects [192,193]. Treatment with physcion exhibited hair growth-promoting activity in testosterone-treated C57BL/ 6 mice [51]. In addition, physcion inhibits $5 \alpha$-reductase expression in vivo [51]. Rosmarinus officinalis belongs to the Lamiaceae family and has been widely studied for its antibacterial, antioxidant, and anticancer activities [194-196]. Murata et al. showed that Rosmarinus officinalis leaf extract improved hair regrowth in mice, as well as $5 \alpha$-reductase inhibitory activity [52]. Avicennia marina is used in traditional medicine for the treatment of skin diseases, rheumatism, ulcers, and smallpox [197]. Avicequinone C, isolated from Avicennia marina, attenuated $5 \alpha$-reductase inhibitory activity ( $\mathrm{IC}_{50}$ of $\left.38.8 \pm 1.29 \mu \mathrm{M}\right)$ [53]. 
Ecklonia cava, an edible marine brown alga, contains a variety of bioactive compounds, including phlorotannins, carotenoids, and fucoidans [198]. Ecklonia cava has been reported to have various biological properties, including antioxidant, anti-inflammatory, anti-allergy, and anticancer effects [199]. Shin et al., showed that Ecklonia cava polyphenols reduced oxidative stress in hDPCs [54]. It was found that androgens, the main cause of androgen alopecia, increase reactive oxidative species (ROS) in hDPCs in which androgen receptors are overexpressed [54]. In addition, TGF- $\beta$ - 1 secretion induced by androgen was inhibited by an ROS scavenger, indicating that antioxidants can promote hair growth [54]. Topical application of $0.5 \%$ Ecklonia cava enzymatic extract induced anagen progression on the back of C57BL/ 6 mice [200]. Furthermore, the Ecklonia cava enzymatic extract, dieckol, inhibited $5 \alpha$-reductase activity [200].

\subsection{Sonic Hedgehog (Shh) Signaling}

The hedgehog pathway is one of the most important signaling pathways in tissue development, homeostasis, and repair [201]. Hedgehog signaling is triggered by Sonic hedgehog (Shh), Indian hedgehog (Ihh), and Desert hedgehog (Dhh). Shh signaling plays an important role in HF development [202]. Hedgehog signaling occurs through the binding of hedgehog ligands to the receptor Patched (PTCH) 1, which suppresses the activation of Smoothened (SMO). Inhibition of SMO results in the translocation of the glioma-associated (GLI) gene to the nucleus [202]. Shh plays an essential role in the cell-cell interactions involved in the morphogenesis of hair follicles [203]. Hair follicle development results from complex signaling between epithelial and mesenchymal cells. Various signaling pathways are involved in hair follicle development, such as Wnt, bone morphogenetic protein (BMP), platelet-derived growth factor (PDGF), Notch, and ectodysplasin, and they exhibit signaling crosstalk with the hedgehog pathway [201]. RGO treatment upregulated Shh signaling-related expression of Shh, SMO, and GLI1 in testosterone-induced C57BL/6 mice [22] and in mouse skin [38]. TO treatment resulted in an increase in Shh expression [39]. Costunolide elevated GLI1 mRNA and protein expression in hDPCs [43]. Epigallocatechin-3-gallate (EGCG) is a major bioactive molecule in green tea that has been shown to act on multiple molecular targets to ameliorate various human diseases [204]. Green tea leaf extracts have polyphenolic components that exhibit anti-inflammatory and stress-inhibitory effects, which may influence mouse hair growth [205]. EGCG treatment promoted the growth of mink hair follicles and the proliferation of DPCs and outer root sheath cells (ORSCs) [55]. EGCG has also been shown to increase the protein levels of Shh, PTCH, Smo, and Gli1 in hair follicles [55].

\subsection{Apoptosis}

Apoptosis plays an important role in morphological development and is accompanied by a number of characteristic morphological changes, including cell shrinkage, nuclear condensation, and cellular fragmentation [206]. There are two major apoptosis signaling pathways: the death receptor (extrinsic) pathway and the mitochondria-mediated pathway [207]. The extrinsic pathway is initiated by cell-surface-expressed death receptors of the tumor necrosis factor superfamily. Once the receptor is activated, caspase- 8 is activated and initiates apoptosis by direct cleavage of downstream effector caspases [207]. The intrinsic pathway is initiated by intracellular stresses, and it induces permeabilization of the outer mitochondrial membrane and activates the mitochondrial pathway. Once mitochondrial permeabilization occurs, cytochrome $\mathrm{c}$ is released into the cytosol and associates with caspase- 9 and Apaf- 1 to form apoptosomes, which can activate caspase- 3 or caspase-7, causing apoptosis [207]. Apoptosis signaling is attenuated by a particular group of proteins (Bcl-2, Bcl-xL, and Mcl-1) [208]. Another group of proteins (Bax, Bak, Bok, Bim, Bad, Bcl-xS, and Bid) act as apoptotic agonists that promote apoptosis [208]. In the anagen phase, hair follicular cells undergo dynamic cell proliferation and differentiation to form the hair shaft [209]. During the catagen phase, growth factors expressed by DPCs cause a decrease in the proliferation and differentiation of hair matrix keratinocytes, leading 
to apoptosis $[210,211]$. The anagen-catagen transition plays a clinically important role in human hair growth; the abnormal termination of the anagen phase has been shown to cause gradual hair thinning [211]. Therefore, extension of the anagen phase is a key strategy for the prevention of hair loss. Caffeine administration inhibits apoptosis and necrosis in human ORS keratinocytes [20]. The decrease in the protein level of Bcl-2 in testosterone-treated mice was reversed after treatment with RGO, LA, and SITOS [22]. Treatment with RGO after UVC exposure inhibited cleaved caspase-3, cleaved caspase-9, and cleaved poly-ADP ribose polymerase (PARP) expression in mouse skin tissues [38]. In addition, RGO treatment resulted in an increased Bax/Bcl-2 ratio in the UVC-treated group compared to that in the control group [38]. Quercitrin administration resulted in a decrease in mRNA expression of Bad, although the mRNA and protein expression of Bcl-2 increased after treatment of cultured hDPCs with $10 \mathrm{nM}$ and $100 \mathrm{nM}$ quercitrin [23]. PM extract also showed an increase in Bcl-2 mRNA expression and a decrease in Bad expression in hDPCs [30]. Panax ginseng extract inhibited apoptosis in Dickkopf-1 (DKK-1)-induced ORS keratinocytes as determined by terminal deoxynucleotidyl transferase-mediated dUTP nick end labeling (TUNEL) staining [56]. Moreover, Panax ginseng extract downregulated the mRNA expression of Bcl-2 and upregulated the mRNA expression of Bax in DKK-1induced ORS keratinocytes and HF [56]. AS treatment increased protein expression of Bcl-2 but led to a decrease in the protein levels of Bax, PARP, and caspase-3 in HFDPCs [31]. SP extract elevated the protein expression of $\mathrm{Bcl}-2$ and decreased Bax expression compared with the negative or positive control (10 $\mu \mathrm{M}$ minoxidil) in hDPCs [46]. The extract from the berries Serenoa repens (SR), commonly known as saw palmetto, showed therapeutic effects as a $5 \alpha$-reductase inhibitor [212]. SR and DHT co-treatment stimulated hair growth compared to that induced by DHT in vivo [57]. Moreover, SR treatment led to a decrease in the protein expression of TGF- $\beta 2$, cleaved caspase-3, and Bax, but increased Bcl-2 expression compared to DHT treatment [57].

\subsection{Cell Cycle}

Cell proliferation is controlled by factors that regulate the transition between different cell cycle stages in mammalian cells [213]. Cell cycle progression also plays a major role in HF biology [214]. The cell cycle consists of four phases: gap phase 1 (G1), DNA synthesis (S), gap phase 2 (G2), and mitosis (M) [214]. Cyclins and cyclin-dependent kinases (CDKs) function as regulators of the G1/S or G2/M phases [215]. Cyclin D1 binds to CDK4 and CDK6 and drives cell cycle progression into the G1 phase [213]. Cyclin E associates with CDK2 to promote G1-S phase transition [214]. Sinapic acid treatment was accompanied by an increase in cyclin D1 and the distribution of cells in the G0/G1 phase, as well as a decreased distribution in the $S$ and G2/M phases [16]. Cyclin D1 is a direct target for transactivation by the $\beta$-catenin/LEF-1 pathway through an LEF-1 binding site in the cyclin $\mathrm{D} 1$ promoter and is a direct downstream molecule in the $\beta$-catenin pathway [213]. Woo et al. suggested that sinapic acid treatment increased cell growth and cell cycle progression through an increase in cyclin D1 expression [16]. Administration of RGO increased the protein expression of cyclin D1 and cyclin E in testosterone-treated mice [22] and C57BL/6 mouse models [38]. UP treatment upregulated cyclin D1, phospho(ser780)-pRB, cyclin E, phospho-CDK2, and CDK2 protein expression in DPCs [47]. Treatment with IS upregulated cyclin E and CDK2 expression in cultured DPCs [41]. LA in MV seeds increased the mRNA levels of cyclin D1 and CDK2 in vitro [33]. EGCG treatment increased the number of cells in S phase, and upregulated the protein levels of cyclin D1 and cyclin B1 [55].

\section{Conclusions}

This study reviewed the beneficial effects of herbs and their bioactive compounds on hair growth, and their underlying mechanisms of action (growth factors and cytokines, Wnt $/ \beta$-catenin, $5 \alpha$-reductase inhibitory effect, sonic hedgehog signaling, apoptosis, and cell cycle progression). The herbs and their constituents investigated in this study act via multiple signaling mechanisms in the prevention of alopecia. Therefore, they have the 
potential to be more effective than minoxidil and finasteride, which are conventionally used to treat hair loss. In this review, we have attempted to provide a database of phytochemicals for hair-growth-promoting effects. This information will serve as a basis for developing more effective therapeutic agents for the treatment of alopecia and improving our understanding of their mechanisms of action.

Author Contributions: Conceptualization, S.P.; writing—original draft preparation, J.L.; writingreview and editing, S.P. and J.L.; visualization, J.L.; supervision, S.P.; project administration, S.P. and J.L.; funding acquisition, J.L. All authors have read and agreed to the published version of the manuscript.

Funding: This study was supported by a research fund from Chosun University (2021).

Institutional Review Board Statement: Not applicable.

Informed Consent Statement: Not applicable.

Data Availability Statement: Not applicable.

Conflicts of Interest: The authors declare no conflict of interest.

\section{References}

1. Hu, X.M.; Li, Z.X.; Zhang, D.Y.; Yang, Y.C.; Fu, S.A.; Zhang, Z.Q.; Yang, R.H.; Xiong, K. A systematic summary of survival and death signalling during the life of hair follicle stem cells. Stem Cell Res. Ther. 2021, 12, 453. [CrossRef] [PubMed]

2. Schneider, M.R.; Schmidt-Ullrich, R.; Paus, R. The hair follicle as a dynamic miniorgan. Curr. Biol. 2009, 19, R132-R142. [CrossRef]

3. Blume-Peytavi, U.; Whiting, D.A.; Trüeb, R.M. Hair Growth and Disorders; Springer Science \& Business Media: Berlin/Heidelberg, Germany, 2008.

4. Wells, P.A.; Willmoth, T.; Russell, R.J. Does fortune favour the bald? Psychological correlates of hair loss in males. Br. J. Psychol. 1995, 86, 337-344. [CrossRef]

5. Paus, R.; Cotsarelis, G. The biology of hair follicles. N. Engl. J. Med. 1999, 341, 491-497. [CrossRef] [PubMed]

6. Danilenko, D.M.; Ring, B.D.; Pierce, G.F. Growth factors and cytokines in hair follicle development and cycling: Recent insights from animal models and the potentials for clinical therapy. Mol. Med. Today 1996, 2, 460-467. [CrossRef]

7. Kos, L.; Conlon, J. An update on alopecia areata. Curr. Opin. Pediatr. 2009, 21, 475-480. [CrossRef]

8. Wasserman, D.; Guzman-Sanchez, D.A.; Scott, K.; McMichael, A. Alopecia areata. Int. J. Derm. 2007, 46, 121-131. [CrossRef] [PubMed]

9. Harrison, S.; Sinclair, R. Telogen effluvium. Clin. Exp. Derm. 2002, 27, 389-395. [CrossRef] [PubMed]

10. Tosti, A.; Piraccini, B.M.; Sisti, A.; Duque-Estrada, B. Hair loss in women. Minerva Ginecol. 2009, 61, 445-452.

11. Harries, M.J.; Paus, R. The pathogenesis of primary cicatricial alopecias. Am. J. Pathol. 2010, 177, 2152-2162. [CrossRef] [PubMed]

12. Messenger, A.G.; Rundegren, J. Minoxidil: Mechanisms of action on hair growth. Br. J. Derm. 2004, 150, 186-194. [CrossRef]

13. Kaufman, K.D.; Olsen, E.A.; Whiting, D.; Savin, R.; DeVillez, R.; Bergfeld, W.; Price, V.H.; Van Neste, D.; Roberts, J.L.; Hordinsky, M. Finasteride in the treatment of men with androgenetic alopecia. J. Am. Acad. Dermatol. 1998, 39, 578-589. [CrossRef]

14. Jain, P.K.; Das, D.; Singhai, A. Alternative herbal drugs used for treating hair disease. Asian J. Pharm. Clin. Res. 2016, 9, 75-77.

15. Działo, M.; Mierziak, J.; Korzun, U.; Preisner, M.; Szopa, J.; Kulma, A. The potential of plant phenolics in prevention and therapy of skin disorders. Int. J. Mol. Sci. 2016, 17, 160. [CrossRef] [PubMed]

16. Woo, H.; Lee, S.; Kim, S.; Park, D.; Jung, E. Effect of sinapic acid on hair growth promoting in human hair follicle dermal papilla cells via Akt activation. Arch. Derm. Res. 2017, 309, 381-388. [CrossRef]

17. Su, Y.S.; Fan, Z.X.; Xiao, S.E.; Lin, B.J.; Miao, Y.; Hu, Z.Q.; Liu, H. Icariin promotes mouse hair follicle growth by increasing insulin-like growth factor 1 expression in dermal papillary cells. Clin. Exp. Derm. 2017, 42, 287-294. [CrossRef] [PubMed]

18. Boisvert, W.A.; Yu, M.; Choi, Y.; Jeong, G.H.; Zhang, Y.L.; Cho, S.; Choi, C.; Lee, S.; Lee, B.H. Hair growth-promoting effect of Geranium sibiricum extract in human dermal papilla cells and C57BL/6 mice. BMC Complement. Altern. Med. 2017, 17, 109. [CrossRef]

19. Tong, T.; Kim, N.; Park, T. Topical Application of Oleuropein Induces Anagen Hair Growth in Telogen Mouse Skin. PLoS ONE 2015, 10, e0129578. [CrossRef]

20. Fischer, T.W.; Herczeg-Lisztes, E.; Funk, W.; Zillikens, D.; Biro, T.; Paus, R. Differential effects of caffeine on hair shaft elongation, matrix and outer root sheath keratinocyte proliferation, and transforming growth factor-beta2/insulin-like growth factor-1mediated regulation of the hair cycle in male and female human hair follicles in vitro. Br. J. Derm. 2014, 171, 1031-1043. [CrossRef]

21. Junlatat, J.; Sripanidkulchai, B. Hair growth-promoting effect of Carthamus tinctorius floret extract. Phytother. Res. 2014, 28, 1030-1036. [CrossRef]

22. Truong, V.L.; Bak, M.J.; Lee, C.; Jun, M.; Jeong, W.S. Hair Regenerative Mechanisms of Red Ginseng Oil and Its Major Components in the Testosterone-Induced Delay of Anagen Entry in C57BL/6 Mice. Molecules 2017, 22. [CrossRef] 
23. Kim, J.; Kim, S.R.; Choi, Y.H.; Shin, J.Y.; Kim, C.D.; Kang, N.G.; Park, B.C.; Lee, S. Quercitrin Stimulates Hair Growth with Enhanced Expression of Growth Factors via Activation of MAPK/CREB Signaling Pathway. Molecules 2020, 25, 4004. [CrossRef] [PubMed]

24. Roh, S.S.; Kim, C.D.; Lee, M.H.; Hwang, S.L.; Rang, M.J.; Yoon, Y.K. The hair growth promoting effect of Sophora flavescens extract and its molecular regulation. J. Derm. Sci. 2002, 30, 43-49. [CrossRef]

25. Choi, M.; Choi, S.J.; Jang, S.; Choi, H.I.; Kang, B.M.; Hwang, S.T.; Kwon, O. Shikimic acid, a mannose bioisostere, promotes hair growth with the induction of anagen hair cycle. Sci. Rep. 2019, 9, 17008. [CrossRef]

26. Lim, W.; Mudge, K.W.; Vermeylen, F. Effects of population, age, and cultivation methods on ginsenoside content of wild American ginseng (Panax quinquefolium). J. Agric. Food Chem. 2005, 53, 8498-8505. [CrossRef]

27. Zhang, H.; Su, Y.; Wang, J.; Gao, Y.; Yang, F.; Li, G.; Shi, Q. Ginsenoside Rb1 promotes the growth of mink hair follicle via PI3K/AKT/GSK-3beta signaling pathway. Life Sci. 2019, 229, 210-218. [CrossRef]

28. Park, H.J.; Jin, G.R.; Jung, J.H.; Hwang, S.B.; Lee, S.H.; Lee, B.H. Hair Growth Promotion Effect of Nelumbinis Semen Extract with High Antioxidant Activity. Evid. Based Complement. Altern. Med. 2021, 2021, 6661373. [CrossRef] [PubMed]

29. Park, Y.O.; Kim, S.E.; Kim, Y.C. Action Mechanism of Chamaecyparis obtusa Oil on Hair Growth. Toxicol. Res. 2013, 29, 241-247. [CrossRef]

30. Shin, J.Y.; Choi, Y.H.; Kim, J.; Park, S.Y.; Nam, Y.J.; Lee, S.Y.; Jeon, J.H.; Jin, M.H.; Lee, S. Polygonum multiflorum extract support hair growth by elongating anagen phase and abrogating the effect of androgen in cultured human dermal papilla cells. BMC Complement. Med. Ther. 2020, 20, 144. [CrossRef]

31. Ha, E.J.; Yun, J.H.; Si, C.; Bae, Y.S.; Jeong, Y.H.; Park, K.H.; Choi, S.E. Application of Ethanol Extracts From Alnus sibirica Fisch. ex Turcz in Hair Growth Promotion. Front. Bioeng. Biotechnol. 2021, 9, 673314. [CrossRef]

32. Lee, E.Y.; Choi, E.J.; Kim, J.A.; Hwang, Y.L.; Kim, C.D.; Lee, M.H.; Roh, S.S.; Kim, Y.H.; Han, I.; Kang, S. Malva verticillata seed extracts upregulate the Wnt pathway in human dermal papilla cells. Int. J. Cosmet. Sci. 2016, 38, 148-154. [CrossRef] [PubMed]

33. Ryu, H.S.; Jeong, J.; Lee, C.M.; Lee, K.S.; Lee, J.N.; Park, S.M.; Lee, Y.M. Activation of Hair Cell Growth Factors by Linoleic Acid in Malva verticillata Seed. Molecules 2021, 26. [CrossRef] [PubMed]

34. Li, S.; Chen, J.; Chen, F.; Wang, C.; Guo, X.; Wang, C.; Fan, Y.; Wang, Y.; Peng, Y.; Li, W. Liposomal honokiol promotes hair growth via activating Wnt3a/beta-catenin signaling pathway and down regulating TGF-beta1 in C57BL/6N mice. Biomed. Pharm. 2021, 141, 111793. [CrossRef]

35. Lee, T.K.; Kim, B.; Kim, D.W.; Ahn, J.H.; Sim, H.; Lee, J.C.; Yang, G.E.; Her, Y.; Park, J.H.; Kim, H.S.; et al. Effects of Decursin and Angelica gigas Nakai Root Extract on Hair Growth in Mouse Dorsal Skin via Regulating Inflammatory Cytokines. Molecules 2020, 25, 3697. [CrossRef]

36. Kim, Y.E.; Choi, H.C.; Lee, I.C.; Yuk, D.Y.; Lee, H.; Choi, B.Y. 3-Deoxysappanchalcone Promotes Proliferation of Human Hair Follicle Dermal Papilla Cells and Hair Growth in C57BL/ 6 Mice by Modulating WNT/beta-Catenin and STAT Signaling. Biomol. Ther. 2016, 24, 572-580. [CrossRef]

37. Lee, Y.H.; Nam, G.; Kim, M.-K.; Cho, S.-C.; Choi, B.Y. Broussonetia papyrifera Promotes Hair Growth Through the Regulation of $\beta$-Catenin and STAT6 Target Proteins: A Phototrichogram Analysis of Clinical Samples. Cosmetics 2020, 7, 40. [CrossRef]

38. Truong, V.L.; Keum, Y.S.; Jeong, W.S. Red ginseng oil promotes hair growth and protects skin against UVC radiation. J. Ginseng Res. 2021, 45, 498-509. [CrossRef]

39. Zhang, N.N.; Park, D.K.; Park, H.J. Hair growth-promoting activity of hot water extract of Thuja orientalis. BMC Complement. Altern. Med. 2013, 13, 9. [CrossRef]

40. Bejaoui, M.; Villareal, M.O.; Isoda, H. $\beta$-catenin-mediated hair growth induction effect of 3, 4, 5-tri-O-caffeoylquinic acid. Aging 2019, 11, 4216. [CrossRef]

41. Kang, J.I.; Kim, E.J.; Kim, M.K.; Jeon, Y.J.; Kang, S.M.; Koh, Y.S.; Yoo, E.S.; Kang, H.K. The promoting effect of Ishige sinicola on hair growth. Mar. Drugs 2013, 11, 1783-1799. [CrossRef]

42. Zhou, Y.; Tang, G.; Li, X.; Sun, W.; Liang, Y.; Gan, D.; Liu, G.; Song, W.; Wang, Z. Study on the chemical constituents of nut oil from Prunus mira Koehne and the mechanism of promoting hair growth. J. Ethnopharmacol. 2020, 258, 112831. [CrossRef]

43. Kim, Y.E.; Choi, H.C.; Nam, G.; Choi, B.Y. Costunolide promotes the proliferation of human hair follicle dermal papilla cells and induces hair growth in C57BL/ 6 mice. J. Cosmet. Derm. 2019, 18, 414-421. [CrossRef] [PubMed]

44. Zhou, L.; Wang, H.; Jing, J.; Yu, L.; Wu, X.; Lu, Z. Morroniside regulates hair growth and cycle transition via activation of the Wnt/ $\beta$-catenin signaling pathway. Sci. Rep. 2018, 8, 13785. [CrossRef] [PubMed]

45. Xiao, L.; Zhang, X.; Chen, Z.; Li, J.; Li, B.; Li, L. Molecular Pathways Involved in Promoting Activity of Timosaponin BII on Hair Growth in C57BL/6 Mice. Biomed. Res. Int. 2020, 2020, 9451596. [CrossRef] [PubMed]

46. Jin, G.R.; Zhang, Y.L.; Yap, J.; Boisvert, W.A.; Lee, B.H. Hair growth potential of Salvia plebeia extract and its associated mechanisms. Pharm. Biol. 2020, 58, 400-409. [CrossRef]

47. Kang, J.-I.; Kim, M.-K.; Lee, J.-H.; Jeon, Y.-J.; Hwang, E.-K.; Koh, Y.-S.; Hyun, J.-W.; Kwon, S.-Y.; Yoo, E.-S.; Kang, H.-K. Undariopsis peterseniana promotes hair growth by the activation of Wnt/ $\beta$-catenin and ERK pathways. Mar. Drugs 2017, 15, 130. [CrossRef] [PubMed]

48. Murata, K.; Noguchi, K.; Kondo, M.; Onishi, M.; Watanabe, N.; Okamura, K.; Matsuda, H. Inhibitory activities of Puerariae Flos against testosterone 5alpha-reductase and its hair growth promotion activities. J. Nat. Med. 2012, 66, 158-165. [CrossRef] 
49. Zhang, B.; Zhang, R.; Yin, X.; Lao, Z.; Zhang, Z.; Wu, Q.; Yu, L.; Lai, X.; Wan, Y.; Li, G. Inhibitory activities of some traditional Chinese herbs against testosterone $5 \alpha$-reductase and effects of Cacumen platycladi on hair re-growth in testosterone-treated mice. J. Ethnopharmacol. 2016, 177, 1-9. [CrossRef] [PubMed]

50. Murata, K.; Takeshita, F.; Samukawa, K.; Tani, T.; Matsuda, H. Effects of ginseng rhizome and ginsenoside Ro on testosterone 5alpha-reductase and hair re-growth in testosterone-treated mice. Phytother. Res. 2012, 26, 48-53. [CrossRef]

51. Lao, Z.; Fan, Y.; Huo, Y.; Liao, F.; Zhang, R.; Zhang, B.; Kong, Z.; Long, H.; Xie, J.; Sang, C.; et al. Physcion, a novel inhibitor of $5 \alpha$-reductase that promotes hair growth in vitro and in vivo. Arch. Derm. Res. 2021. [CrossRef]

52. Murata, K.; Noguchi, K.; Kondo, M.; Onishi, M.; Watanabe, N.; Okamura, K.; Matsuda, H. Promotion of hair growth by Rosmarinus officinalis leaf extract. Phytother. Res. 2013, 27, 212-217. [CrossRef]

53. Jain, R.; Monthakantirat, O.; Tengamnuay, P.; De-Eknamkul, W. Avicequinone C isolated from Avicennia marina exhibits $5 \alpha-$ reductase-type 1 inhibitory activity using an androgenic alopecia relevant cell-based assay system. Molecules 2014, 19, 6809-6821. [CrossRef] [PubMed]

54. Shin, H.; Yoo, H.G.; Inui, S.; Itami, S.; Kim, I.G.; Cho, A.-R.; Lee, D.H.; Park, W.S.; Kwon, O.; Cho, K.H. Induction of transforming growth factor-beta 1 by androgen is mediated by reactive oxygen species in hair follicle dermal papilla cells. BMB Rep. 2013, 46, 460. [CrossRef]

55. Zhang, H.; Nan, W.; Wang, S.; Song, X.; Si, H.; Li, T.; Li, G. Epigallocatechin-3-Gallate promotes the growth of mink hair follicles through sonic hedgehog and protein kinase B signaling pathways. Front. Pharmacol. 2018, 9, 674. [CrossRef]

56. Lee, Y.; Kim, S.N.; Hong, Y.D.; Park, B.C.; Na, Y. Panax ginseng extract antagonizes the effect of DKK1-induced catagen-like changes of hair follicles. Int. J. Mol. Med. 2017, 40, 1194-1200. [CrossRef] [PubMed]

57. Zhu, H.L.; Gao, Y.H.; Yang, J.Q.; Li, J.B.; Gao, J. Serenoa repens extracts promote hair regeneration and repair of hair loss mouse models by activating TGF-beta and mitochondrial signaling pathway. Eur. Rev. Med. Pharm. Sci. 2018, 22, 4000-4008. [CrossRef]

58. Miele, C.; Rochford, J.J.; Filippa, N.; Giorgetti-Peraldi, S.; Van Obberghen, E. Insulin and insulin-like growth factor-I induce vascular endothelial growth factor mRNA expression via different signaling pathways. J. Biol. Chem. 2000, 275, 21695-21702. [CrossRef] [PubMed]

59. Ozeki, M.; Tabata, Y. In vivo promoted growth of mice hair follicles by the controlled release of growth factors. Biomaterials 2003, 24, 2387-2394. [CrossRef]

60. Peus, D.; Pittelkow, M.R. Growth factors in hair organ development and the hair growth cycle. Derm. Clin. 1996, 14, 559-572. [CrossRef]

61. Philpott, M.P.; Sanders, D.A.; Kealey, T. Effects of insulin and insulin-like growth factors on cultured human hair follicles: IGF-I at physiologic concentrations is an important regulator of hair follicle growth in vitro. J. Investig. Dermatol. 1994, 102, 857-861. [CrossRef]

62. Castela, M.; Linay, F.; Roy, E.; Moguelet, P.; Xu, J.; Holzenberger, M.; Khosrotehrani, K.; Aractingi, S. Igf1r signalling acts on the anagen-to-catagen transition in the hair cycle. Exp. Dermatol. 2017, 26, 785-791. [CrossRef] [PubMed]

63. Shi, H.X.; Lin, C.; Lin, B.B.; Wang, Z.G.; Zhang, H.Y.; Wu, F.Z.; Cheng, Y.; Xiang, L.J.; Guo, D.J.; Luo, X.; et al. The anti-scar effects of basic fibroblast growth factor on the wound repair in vitro and in vivo. PLoS ONE 2013, 8, e59966. [CrossRef] [PubMed]

64. Jang, J.H. Stimulation of human hair growth by the recombinant human keratinocyte growth factor-2 (KGF-2). Biotechnol. Lett. 2005, 27, 749-752. [CrossRef] [PubMed]

65. Jindo, T.; Tsuboi, R.; Imai, R.; Takamori, K.; Rubin, J.S.; Ogawa, H. Hepatocyte growth factor/scatter factor stimulates hair growth of mouse vibrissae in organ culture. J. Investig. Dermatol. 1994, 103, 306-309. [CrossRef]

66. Jindo, T.; Tsuboi, R.; Takamori, K.; Ogawa, H. Local injection of hepatocyte growth factor/scatter factor (HGF/SF) alters cyclic growth of murine hair follicles. J. Investig. Dermatol. 1998, 110, 338-342. [CrossRef]

67. Soma, T.; Dohrmann, C.E.; Hibino, T.; Raftery, L.A. Profile of transforming growth factor-beta responses during the murine hair cycle. J. Investig. Dermatol. 2003, 121, 969-975. [CrossRef] [PubMed]

68. Chen, C. Sinapic Acid and Its Derivatives as Medicine in Oxidative Stress-Induced Diseases and Aging. Oxid. Med. Cell Longev. 2016, 2016, 3571614. [CrossRef]

69. Huang, X.; Pan, Q.; Mao, Z.; Zhang, R.; Ma, X.; Xi, Y.; You, H. Sinapic Acid Inhibits the IL-1beta-Induced Inflammation via MAPK Downregulation in Rat Chondrocytes. Inflammation 2018, 41, 562-568. [CrossRef]

70. Yun, K.J.; Koh, D.J.; Kim, S.H.; Park, S.J.; Ryu, J.H.; Kim, D.G.; Lee, J.Y.; Lee, K.T. Anti-inflammatory effects of sinapic acid through the suppression of inducible nitric oxide synthase, cyclooxygase-2, and proinflammatory cytokines expressions via nuclear factor-kappaB inactivation. J. Agric. Food Chem. 2008, 56, 10265-10272. [CrossRef]

71. Eroglu, C.; Avci, E.; Vural, H.; Kurar, E. Anticancer mechanism of Sinapic acid in PC-3 and LNCaP human prostate cancer cell lines. Gene 2018, 671, 127-134. [CrossRef]

72. Cherng, Y.G.; Tsai, C.C.; Chung, H.H.; Lai, Y.W.; Kuo, S.C.; Cheng, J.T. Antihyperglycemic action of sinapic acid in diabetic rats. J. Agric. Food Chem. 2013, 61, 12053-12059. [CrossRef]

73. Lee, H.E.; Kim, D.H.; Park, S.J.; Kim, J.M.; Lee, Y.W.; Jung, J.M.; Lee, C.H.; Hong, J.G.; Liu, X.; Cai, M.; et al. Neuroprotective effect of sinapic acid in a mouse model of amyloid beta(1-42) protein-induced Alzheimer's disease. Pharm. Biochem. Behav. 2012, 103, 260-266. [CrossRef] [PubMed]

74. Zhang, Z.B.; Yang, Q.T. The testosterone mimetic properties of icariin. Asian J. Ther. 2006, 8, 601-605. [CrossRef] [PubMed] 
75. Nian, H.; Ma, M.H.; Nian, S.S.; Xu, L.L. Antiosteoporotic activity of icariin in ovariectomized rats. Phytomedicine 2009, 16, 320-326. [CrossRef] [PubMed]

76. Pan, Y.; Kong, L.; Xia, X.; Zhang, W.; Xia, Z.; Jiang, F. Antidepressant-like effect of icariin and its possible mechanism in mice. Pharm. Biochem. Behav. 2005, 82, 686-694. [CrossRef]

77. Shim, J.U.; Lim, K.T. Antioxidative activity of glycoprotein isolated from Geranium sibiricum Linne. Nat. Prod. Res. 2009, 23, 375-387. [CrossRef]

78. Shim, J.U.; Oh, P.S.; Lim, K.T. Anti-inflammatory activity of ethanol extract from Geranium sibiricum Linne. J. Ethnopharmacol. 2009, 126, 90-95. [CrossRef]

79. Wu, N.; Zu, Y.; Fu, Y.; Kong, Y.; Zhao, J.; Li, X.; Li, J.; Wink, M.; Efferth, T. Antioxidant activities and xanthine oxidase inhibitory effects of extracts and main polyphenolic compounds obtained from Geranium sibiricum L. J. Agric. Food Chem. 2010, 58, 4737-4743. [CrossRef] [PubMed]

80. Barbaro, B.; Toietta, G.; Maggio, R.; Arciello, M.; Tarocchi, M.; Galli, A.; Balsano, C. Effects of the olive-derived polyphenol oleuropein on human health. Int. J. Mol. Sci. 2014, 15, 18508-18524. [CrossRef] [PubMed]

81. Shamshoum, H.; Vlavcheski, F.; Tsiani, E. Anticancer effects of oleuropein. Biofactors 2017, 43, 517-528. [CrossRef]

82. Omar, S.H. Cardioprotective and neuroprotective roles of oleuropein in olive. Saudi Pharm. J. 2010, 18, 111-121. [CrossRef]

83. Fredholm, B.B.; Battig, K.; Holmen, J.; Nehlig, A.; Zvartau, E.E. Actions of caffeine in the brain with special reference to factors that contribute to its widespread use. Pharm. Rev. 1999, 51, 83-133.

84. Kolahdouzan, M.; Hamadeh, M.J. The neuroprotective effects of caffeine in neurodegenerative diseases. CNS Neurosci. Ther. 2017, 23, 272-290. [CrossRef] [PubMed]

85. Hall, S.; Desbrow, B.; Anoopkumar-Dukie, S.; Davey, A.K.; Arora, D.; McDermott, C.; Schubert, M.M.; Perkins, A.V.; Kiefel, M.J.; Grant, G.D. A review of the bioactivity of coffee, caffeine and key coffee constituents on inflammatory responses linked to depression. Food Res. Int. 2015, 76, 626-636. [CrossRef] [PubMed]

86. Sabisz, M.; Skladanowski, A. Modulation of cellular response to anticancer treatment by caffeine: Inhibition of cell cycle checkpoints, DNA repair and more. Curr. Pharm. Biotechnol. 2008, 9, 325-336. [CrossRef]

87. Zhou, X.; Tang, L.; Xu, Y.; Zhou, G.; Wang, Z. Towards a better understanding of medicinal uses of Carthamus tinctorius L. in traditional Chinese medicine: A phytochemical and pharmacological review. J. Ethnopharmacol. 2014, 151, 27-43. [CrossRef] [PubMed]

88. Delshad, E.; Yousefi, M.; Sasannezhad, P.; Rakhshandeh, H.; Ayati, Z. Medical uses of Carthamus tinctorius L. (Safflower): A comprehensive review from Traditional Medicine to Modern Medicine. Electron. Physician 2018, 10, 6672-6681. [CrossRef]

89. Kumar, N.; Rungseevijitprapa, W.; Narkkhong, N.A.; Suttajit, M.; Chaiyasut, C. 5alpha-reductase inhibition and hair growth promotion of some Thai plants traditionally used for hair treatment. J. Ethnopharmacol. 2012, 139, 765-771. [CrossRef] [PubMed]

90. Bak, M.J.; Jun, M.; Jeong, W.S. Antioxidant and hepatoprotective effects of the red ginseng essential oil in $\mathrm{H}(2) \mathrm{O}(2)$-treated hepG2 cells and CCl(4)-treated mice. Int. J. Mol. Sci. 2012, 13, 2314-2330. [CrossRef] [PubMed]

91. Bak, M.J.; Hong, S.G.; Lee, J.W.; Jeong, W.S. Red ginseng marc oil inhibits iNOS and COX-2 via NfkappaB and p38 pathways in LPS-stimulated RAW 264.7 macrophages. Molecules 2012, 17, 13769-13786. [CrossRef] [PubMed]

92. Lee, S.; Youn, K.; Jun, M. Major compounds of red ginseng oil attenuate Abeta25-35-induced neuronal apoptosis and inflammation by modulating MAPK/NF-kappaB pathway. Food Funct. 2018, 9, 4122-4134. [CrossRef] [PubMed]

93. Bak, M.J.; Truong, V.L.; Ko, S.Y.; Nguyen, X.N.; Jun, M.; Hong, S.G.; Lee, J.W.; Jeong, W.S. Induction of Nrf2/ ARE-mediated cytoprotective genes by red ginseng oil through ASK1-MKK4/7-JNK and p38 MAPK signaling pathways in HepG2 cells. J. Ginseng Res. 2016, 40, 423-430. [CrossRef] [PubMed]

94. Lee, S.K.; Oh, K.H.; Chung, A.Y.; Park, H.C.; Lee, S.H.; Kwon, S.Y.; Choi, J. Protective role of quercetin against cisplatin-induced hair cell damage in zebrafish embryos. Hum. Exp. Toxicol. 2015, 34, 1043-1052. [CrossRef] [PubMed]

95. Jin, J.H.; Kim, J.S.; Kang, S.S.; Son, K.H.; Chang, H.W.; Kim, H.P. Anti-inflammatory and anti-arthritic activity of total flavonoids of the roots of Sophora flavescens. J. Ethnopharmacol. 2010, 127, 589-595. [CrossRef] [PubMed]

96. Piao, X.L.; Piao, X.S.; Kim, S.W.; Park, J.H.; Kim, H.Y.; Cai, S.Q. Identification and characterization of antioxidants from Sophora flavescens. Biol. Pharm. Bull. 2006, 29, 1911-1915. [CrossRef] [PubMed]

97. Batory, M.; Rotsztejn, H. Shikimic acid in the light of current knowledge. J. Cosmet. Dermatol. 2021. [CrossRef]

98. Quinde-Axtell, Z.; Baik, B.K. Phenolic compounds of barley grain and their implication in food product discoloration. J. Agric. Food Chem. 2006, 54, 9978-9984. [CrossRef]

99. Kamimura, A.; Takahashi, T. Procyanidin B-3, isolated from barley and identified as a hair-growth stimulant, has the potential to counteract inhibitory regulation by TGF- $\beta 1$. Exp. Dermatol. 2002, 11, 532-541. [CrossRef] [PubMed]

100. Choi, B.Y. Hair-Growth Potential of Ginseng and Its Major Metabolites: A Review on Its Molecular Mechanisms. Int. J. Mol. Sci. 2018, 19, 2703. [CrossRef]

101. Huang, B.; Ban, X.; He, J.; Tong, J.; Tian, J.; Wang, Y. Comparative analysis of essential oil components and antioxidant activity of extracts of Nelumbo nucifera from various areas of China. J. Agric. Food Chem. 2010, 58, 441-448. [CrossRef]

102. Arooj, M.; Imran, S.; Inam-Ur-Raheem, M.; Rajoka, M.S.R.; Sameen, A.; Siddique, R.; Sahar, A.; Tariq, S.; Riaz, A.; Hussain, A.; et al. Lotus seeds (Nelumbinis semen) as an emerging therapeutic seed: A comprehensive review. Food Sci. Nutr. 2021, 9, 3971-3987. [CrossRef] 
103. Zhang, Y.; Lu, X.; Zeng, S.; Huang, X.; Guo, Z.; Zheng, Y.; Tian, Y.; Zheng, B. Nutritional composition, physiological functions and processing of lotus (Nelumbo nucifera Gaertn.) seeds: A review. Phytochem. Rev. 2015, 14, 321-334. [CrossRef]

104. Yang, J.K.; Choi, M.S.; Seo, W.T.; Rinker, D.L.; Han, S.W.; Cheong, G.W. Chemical composition and antimicrobial activity of Chamaecyparis obtusa leaf essential oil. Fitoterapia 2007, 78, 149-152. [CrossRef]

105. Bae, M.S.; Park, D.H.; Choi, C.Y.; Kim, G.Y.; Yoo, J.C.; Cho, S.S. Essential Oils and Non-volatile Compounds Derived from Chamaecyparis obtusa: Broad Spectrum Antimicrobial Activity against Infectious Bacteria and MDR (multidrug resistant) Strains. Nat. Prod. Commun. 2016, 11, 693-694. [CrossRef]

106. An, B.S.; Kang, J.H.; Yang, H.; Jung, E.M.; Kang, H.S.; Choi, I.G.; Park, M.J.; Jeung, E.B. Anti-inflammatory effects of essential oils from Chamaecyparis obtusa via the cyclooxygenase-2 pathway in rats. Mol. Med. Rep. 2013, 8, 255-259. [CrossRef] [PubMed]

107. Park, Y.; Jung, S.M.; Yoo, S.A.; Kim, W.U.; Cho, C.S.; Park, B.J.; Woo, J.M.; Yoon, C.H. Antinociceptive and anti-inflammatory effects of essential oil extracted from Chamaecyparis obtusa in mice. Int. Immunopharmacol. 2015, 29, 320-325. [CrossRef] [PubMed]

108. Bounda, G.A.; Feng, Y.U. Review of clinical studies of Polygonum multiflorum Thunb. and its isolated bioactive compounds. Pharmacogn. Res. 2015, 7, 225-236. [CrossRef]

109. Lv, L.; Gu, X.H.; Tang, J.; Ho, C.T. Antioxidant activity of stilbene glycoside from Polygonum multiflorum Thunb in vivo. Food Chem. 2007, 104, 1678-1681. [CrossRef]

110. Lin, H.W.; Sun, M.X.; Wang, Y.H.; Yang, L.M.; Yang, Y.R.; Huang, N.; Xuan, L.J.; Xu, Y.M.; Bai, D.L.; Zheng, Y.T.; et al. Anti-HIV activities of the compounds isolated from Polygonum cuspidatum and Polygonum multiflorum. Planta Med. 2010, 76, 889-892. [CrossRef]

111. Li, X.; Matsumoto, K.; Murakami, Y.; Tezuka, Y.; Wu, Y.; Kadota, S. Neuroprotective effects of Polygonum multiflorum on nigrostriatal dopaminergic degeneration induced by paraquat and maneb in mice. Pharm. Biochem. Behav. 2005, 82, 345-352. [CrossRef]

112. Um, M.Y.; Choi, W.H.; Aan, J.Y.; Kim, S.R.; Ha, T.Y. Protective effect of Polygonum multiflorum Thunb on amyloid beta-peptide 25-35 induced cognitive deficits in mice. J. Ethnopharmacol. 2006, 104, 144-148. [CrossRef] [PubMed]

113. Xue, X.; Quan, Y.; Gong, L.; Gong, X.; Li, Y. A review of the processed Polygonum multiflorum (Thunb.) for hepatoprotection: Clinical use, pharmacology and toxicology. J. Ethnopharmacol. 2020, 261, 113121. [CrossRef] [PubMed]

114. Asakawa, Y.; Genjida, F.; Suga, T. Four new flavonoids isolated from Alnus sieboldiana. Bull. Chem. Soc. Jpn. 1971, $44,297$. [CrossRef]

115. Ishimatsu, M.; Tanaka, T.; Nonaka, G.-i.; Nishioka, I. Alnusnins A and B from the leaves of Alnus sieboldiana. Phytochemistry 1989, 28, 3179-3184. [CrossRef]

116. Yoshida, T.; Yazaki, K.; Memon, M.U.; Maruyama, I.; Kurokawa, K.; Shingu, T.; Okuda, T. Structures of alnusiin and bicornin, new hydrolyzable tannins having a monolactonized tergalloyl group. Chem. Pharm. Bull. 1989, 37, 2655-2660. [CrossRef]

117. Kuroyanagi, M.; Shimomae, M.; Nagashima, Y.; Muto, N.; Okuda, T.; Kawahara, N.; Nakane, T.; Sano, T. New diarylheptanoids from Alnus japonica and their antioxidative activity. Chem. Pharm. Bull. 2005, 53, 1519-1523. [CrossRef] [PubMed]

118. de Oliveira, L.P.; Bovini, M.G.; da Costa Bortoluzzi, R.L.; Boff, M.I.C.; Boff, P. Species of Malva L.(Malvaceae) cultivated in the western of santa Catarina state and conformity with species marketed as medicinal plants in southern Brazil. J. Agric. Sci. 2019, 11, 171-180. [CrossRef]

119. Bao, L.; Bao, X.; Li, P.; Wang, X.; Ao, W. Chemical profiling of Malva verticillata L. by UPLC-Q-TOF-MSE and their antioxidant activity in vitro. J. Pharm. Biomed. Anal. 2018, 150, 420-426. [CrossRef] [PubMed]

120. Tomoda, M.; Shimizu, N.; Gonda, R.; Kanari, M.; Yamada, H.; Hikino, H. Anti-complementary and hypoglycemic activities of the glycans from the seeds of Malva verticillata. Planta Med. 1990, 56, 168-170. [CrossRef]

121. Jeong, Y.T.; Song, C.H. Antidiabetic activities of extract from Malva verticillata seed via the activation of AMP-activated protein kinase. J. Microbiol. Biotechnol. 2011, 21, 921-929. [CrossRef]

122. Chen, L.; Zhang, Q.; Yang, G.; Fan, L.; Tang, J.; Garrard, I.; Ignatova, S.; Fisher, D.; Sutherland, I.A. Rapid purification and scale-up of honokiol and magnolol using high-capacity high-speed counter-current chromatography. J. Chromatogr. A 2007, 1142, 115-122. [CrossRef] [PubMed]

123. Teng, C.M.; Chen, C.C.; Ko, F.N.; Lee, L.G.; Huang, T.F.; Chen, Y.P.; Hsu, H.Y. Two antiplatelet agents from Magnolia officinalis. Thromb. Res. 1988, 50, 757-765. [CrossRef]

124. Wang, J.; Liu, D.; Guan, S.; Zhu, W.; Fan, L.; Zhang, Q.; Cai, D. Hyaluronic acid-modified liposomal honokiol nanocarrier: Enhance anti-metastasis and antitumor efficacy against breast cancer. Carbohydr. Polym. 2020, 235, 115981. [CrossRef]

125. Jiang, Q.Q.; Fan, L.Y.; Yang, G.L.; Guo, W.H.; Hou, W.L.; Chen, L.J.; Wei, Y.Q. Improved therapeutic effectiveness by combining liposomal honokiol with cisplatin in lung cancer model. BMC Cancer 2008, 8, 242. [CrossRef]

126. Chen, L.; Deng, H.; Cui, H.; Fang, J.; Zuo, Z.; Deng, J.; Li, Y.; Wang, X.; Zhao, L. Inflammatory responses and inflammationassociated diseases in organs. Oncotarget 2018, 9, 7204-7218. [CrossRef] [PubMed]

127. Hoffmann, R.; Eicheler, W.; Huth, A.; Wenzel, E.; Happle, R. Cytokines and growth factors influence hair growth in vitro. Possible implications for the pathogenesis and treatment of alopecia areata. Arch. Derm. Res. 1996, 288, 153-156. [CrossRef] [PubMed]

128. Philpott, M.P.; Sanders, D.A.; Bowen, J.; Kealey, T. Effects of interleukins, colony-stimulating factor and tumour necrosis factor on human hair follicle growth in vitro: A possible role for interleukin-1 and tumour necrosis factor-alpha in alopecia areata. Br. J. Dermatol. 1996, 135, 942-948. [CrossRef] 
129. Hull, S.M.; Nutbrown, M.; Pepall, L.; Thornton, M.J.; Randall, V.A.; Cunliffe, W.J. Immunohistologic and ultrastructural comparison of the dermal papilla and hair follicle bulb from "active" and "normal" areas of alopecia areata. J. Investig. Dermatol. 1991, 96, 673-681. [CrossRef] [PubMed]

130. Groves, R.W.; Mizutani, H.; Kieffer, J.D.; Kupper, T.S. Inflammatory skin disease in transgenic mice that express high levels of interleukin 1 alpha in basal epidermis. Proc. Natl. Acad. Sci. USA 1995, 92, 11874-11878. [CrossRef] [PubMed]

131. Ruckert, R.; Lindner, G.; Bulfone-Paus, S.; Paus, R. High-dose proinflammatory cytokines induce apoptosis of hair bulb keratinocytes in vivo. Br. J. Dermatol. 2000, 143, 1036-1039. [CrossRef] [PubMed]

132. Teraki, Y.; Imanishi, K.; Shiohara, T. Cytokines in alopecia areata: Contrasting cytokine profiles in localized form and extensive form (alopecia universalis). Acta Dermatol. Venereol. 1996, 76, 421-423. [CrossRef] [PubMed]

133. Zhang, J.; Li, L.; Jiang, C.; Xing, C.; Kim, S.H.; Lu, J. Anti-cancer and other bioactivities of Korean Angelica gigas Nakai (AGN) and its major pyranocoumarin compounds. Anticancer Agents Med. Chem. 2012, 12, 1239-1254. [CrossRef]

134. Choi, S.S.; Han, K.J.; Lee, H.K.; Han, E.J.; Suh, H.W. Antinociceptive profiles of crude extract from roots of Angelica gigas NAKAI in various pain models. Biol. Pharm. Bull. 2003, 26, 1283-1288. [CrossRef]

135. Oh, T.W.; Park, K.H.; Jung, H.W.; Park, Y.K. Neuroprotective effect of the hairy root extract of Angelica gigas NAKAI on transient focal cerebral ischemia in rats through the regulation of angiogenesis. BMC Complement. Altern. Med. 2015, 15, 101. [CrossRef] [PubMed]

136. Lee, S.E.; Lim, C.; Cho, S. Angelica gigas root ameliorates ischaemic stroke-induced brain injury in mice by activating the PI3K/AKT/mTOR and MAPK pathways. Pharm. Biol. 2021, 59, 662-671. [CrossRef]

137. Kim, J.H.; Choo, Y.Y.; Tae, N.; Min, B.S.; Lee, J.H. The anti-inflammatory effect of 3-deoxysappanchalcone is mediated by inducing heme oxygenase- 1 via activating the AKT/mTOR pathway in murine macrophages. Int. Immunopharmacol. 2014, 22, 420-426. [CrossRef] [PubMed]

138. Zhao, R.; Huang, H.; Choi, B.Y.; Liu, X.; Zhang, M.; Zhou, S.; Song, M.; Yin, F.; Chen, H.; Shim, J.H.; et al. Cell growth inhibition by 3-deoxysappanchalcone is mediated by directly targeting the TOPK signaling pathway in colon cancer. Phytomedicine 2019, 61 , 152813. [CrossRef]

139. Yodsaoue, O.; Cheenpracha, S.; Karalai, C.; Ponglimanont, C.; Tewtrakul, S. Anti-allergic activity of principles from the roots and heartwood of Caesalpinia sappan on antigen-induced beta-hexosaminidase release. Phytother. Res. 2009, 23, $1028-1031$. [CrossRef] [PubMed]

140. Choi, H.C.; Nam, G.W.; Jeong, N.H.; Choi, B.Y. Hair growth promotion by extracts of Inula Helenium and Caesalpinia Sappan Bark in patients with androgenetic alopecia: A pre-clinical study using phototrichogram analysis. Cosmetics 2019, 6, 66. [CrossRef]

141. Lee, D.; Bhat, K.P.; Fong, H.H.; Farnsworth, N.R.; Pezzuto, J.M.; Kinghorn, A.D. Aromatase inhibitors from Broussonetia papyrifera. J. Nat. Prod. 2001, 64, 1286-1293. [CrossRef] [PubMed]

142. Han, Q.; Wu, Z.; Huang, B.; Sun, L.; Ding, C.; Yuan, S.; Zhang, Z.; Chen, Y.; Hu, C.; Zhou, L.; et al. Extraction, antioxidant and antibacterial activities of Broussonetia papyrifera fruits polysaccharides. Int. J. Biol. Macromol. 2016, 92, 116-124. [CrossRef] [PubMed]

143. Ryu, H.W.; Park, M.H.; Kwon, O.K.; Kim, D.Y.; Hwang, J.Y.; Jo, Y.H.; Ahn, K.S.; Hwang, B.Y.; Oh, S.R. Anti-inflammatory flavonoids from root bark of Broussonetia papyrifera in LPS-stimulated RAW264.7 cells. Bioorg. Chem. 2019, 92, 103233. [CrossRef] [PubMed]

144. Choi, Y.S.; Zhang, Y.; Xu, M.; Yang, Y.; Ito, M.; Peng, T.; Cui, Z.; Nagy, A.; Hadjantonakis, A.K.; Lang, R.A.; et al. Distinct functions for Wnt/beta-catenin in hair follicle stem cell proliferation and survival and interfollicular epidermal homeostasis. Cell Stem Cell 2013, 13, 720-733. [CrossRef] [PubMed]

145. MacDonald, B.T.; Tamai, K.; He, X. Wnt/beta-catenin signaling: Components, mechanisms, and diseases. Dev. Cell 2009, 17, 9-26. [CrossRef]

146. Soma, T.; Fujiwara, S.; Shirakata, Y.; Hashimoto, K.; Kishimoto, J. Hair-inducing ability of human dermal papilla cells cultured under Wnt/beta-catenin signalling activation. Exp. Dermatol. 2012, 21, 307-309. [CrossRef] [PubMed]

147. Kim, T.H.; Li, H.; Wu, Q.; Lee, H.J.; Ryu, J.H. A new labdane diterpenoid with anti-inflammatory activity from Thuja orientalis. J. Ethnopharmacol. 2013, 146, 760-767. [CrossRef] [PubMed]

148. Miyamae, Y.; Han, J.; Sasaki, K.; Terakawa, M.; Isoda, H.; Shigemori, H. 3,4,5-tri-O-caffeoylquinic acid inhibits amyloid betamediated cellular toxicity on SH-SY5Y cells through the upregulation of PGAM1 and G3PDH. Cytotechnology 2011, 63, 191-200. [CrossRef] [PubMed]

149. Miyamae, Y.; Kurisu, M.; Murakami, K.; Han, J.; Isoda, H.; Irie, K.; Shigemori, H. Protective effects of caffeoylquinic acids on the aggregation and neurotoxicity of the 42-residue amyloid beta-protein. Bioorg. Med. Chem. 2012, 20, 5844-5849. [CrossRef] [PubMed]

150. Kim, M.; Kang, J.H.; Oh, G.H.; Park, M.H. Ishige sinicola extract stimulates osteoblast proliferation and differentiation via the bone morphogenetic protein 2/runt-related gene 2 signalling pathway. Z Nat. C J. Biosci. 2019, 74, 167-174. [CrossRef]

151. Ali, I.; Manzoor, Z.; Koo, J.E.; Moon, S.R.; Byeon, S.H.; Yoo, E.S.; Kang, H.K.; Hyun, J.W.; Lee, N.H.; Koh, Y.S. Monoolein, isolated from Ishige sinicola, inhibits lipopolysaccharide-induced inflammatory response by attenuating mitogen-activated protein kinase and NF-kappaB pathways. Food Sci. Biotechnol. 2017, 26, 507-511. [CrossRef] [PubMed] 
152. Ying, H.; Shi, J.; Zhang, S.; Pingcuo, G.; Wang, S.; Zhao, F.; Cui, Y.; Zeng, X. Transcriptomic and metabolomic profiling provide novel insights into fruit development and flesh coloration in Prunus mira Koehne, a special wild peach species. BMC Plant. Biol. 2019, 19, 463. [CrossRef]

153. Peng, Z.X.; Wang, Y.; Gu, X.; Wen, Y.Y.; Yan, C. A platform for fast screening potential anti-breast cancer compounds in traditional Chinese medicines. Biomed. Chromatogr. 2013, 27, 1759-1766. [CrossRef]

154. Lin, X.; Peng, Z.; Su, C. Potential anti-cancer activities and mechanisms of costunolide and dehydrocostuslactone. Int. J. Mol. Sci. 2015, 16, 10888-10906. [CrossRef] [PubMed]

155. Kim, D.Y.; Choi, B.Y. Costunolide-A Bioactive Sesquiterpene Lactone with Diverse Therapeutic Potential. Int. J. Mol. Sci. 2019, 20, 2926. [CrossRef]

156. Kim, S.H.; Lee, M.K.; Ahn, M.J.; Lee, K.Y.; Kim, Y.C.; Sung, S.H. Efficient Method for Extraction and Simultaneous Determination of Active Constituents in Cornus officinalis by Reflux Extraction and High Performance Liquid Chromatography with Diode Array Detection. J. Liq. Chromatogr. R T 2009, 32, 822-832. [CrossRef]

157. Wang, W.; Xu, J.; Li, L.; Wang, P.; Ji, X.; Ai, H.; Zhang, L.; Li, L. Neuroprotective effect of morroniside on focal cerebral ischemia in rats. Brain Res. Bull. 2010, 83, 196-201. [CrossRef] [PubMed]

158. Wang, W.; Huang, W.; Li, L.; Ai, H.; Sun, F.; Liu, C.; An, Y. Morroniside prevents peroxide-induced apoptosis by induction of endogenous glutathione in human neuroblastoma cells. Cell Mol. Neurobiol. 2008, 28, 293-305. [CrossRef]

159. Wang, W.; Sun, F.; An, Y.; Ai, H.; Zhang, L.; Huang, W.; Li, L. Morroniside protects human neuroblastoma SH-SY5Y cells against hydrogen peroxide-induced cytotoxicity. Eur. J. Pharm. 2009, 613, 19-23. [CrossRef] [PubMed]

160. Xie, Q.; Zhao, H.; Li, N.; Su, L.; Xu, X.; Hong, Z. Protective effects of timosaponin BII on oxidative stress damage in PC12 cells based on metabolomics. Biomed. Chromatogr. 2018, 32, e4321. [CrossRef]

161. Li, T.J.; Qiu, Y.; Yang, P.Y.; Rui, Y.C.; Chen, W.S. Timosaponin B-II improves memory and learning dysfunction induced by cerebral ischemia in rats. Neurosci. Lett. 2007, 421, 147-151. [CrossRef]

162. Zhao, X.; Liu, C.; Qi, Y.; Fang, L.; Luo, J.; Bi, K.; Jia, Y. Timosaponin B-II ameliorates scopolamine-induced cognition deficits by attenuating acetylcholinesterase activity and brain oxidative damage in mice. Metab. Brain Dis. 2016, 31, 1455-1461. [CrossRef] [PubMed]

163. King, F.W.; Fong, S.; Griffin, C.; Shoemaker, M.; Staub, R.; Zhang, Y.L.; Cohen, I.; Shtivelman, E. Timosaponin AIII is preferentially cytotoxic to tumor cells through inhibition of mTOR and induction of ER stress. PLoS ONE 2009, 4, e7283. [CrossRef] [PubMed]

164. Xiao, L.; Zhang, X.; Chen, Z.; Li, B.; Li, L. A Timosaponin B-II containing scalp care solution for improvement of scalp hydration, dandruff reduction, and hair loss prevention: A comparative study on healthy volunteers before and after application. J. Cosmet. Dermatol. 2021, 20, 819-824. [CrossRef] [PubMed]

165. Shim, K.S.; Lee, C.J.; Yim, N.H.; Ha, H.; Ma, J.Y. A water extract of Malva verticillata seeds suppresses osteoclastogenesis and bone resorption stimulated by RANK ligand. BMC Complement. Altern. Med. 2016, 16, 332. [CrossRef]

166. Ko, J.H.; Castaneda, R.; Joo, S.W.; Kim, H.G.; Lee, Y.G.; Lee, Y.H.; Kang, T.H.; Baek, N.I. Glycerides isolated from the aerial parts of Malva verticillata cause immunomodulation effects via splenocyte function and NK anti-tumor activity. Food Sci. Biotechnol. 2018, 27, 1023-1030. [CrossRef]

167. Hegazy, M.-E.F.; Mohamed, T.A.; ElShamy, A.I.; Abou-El-Hamd, H.M.; Mahalel, U.A.; Reda, E.H.; Shaheen, A.M.; Tawfik, W.A.; Shahat, A.A.; Shams, K.A. Microbial biotransformation as a tool for drug development based on natural products from mevalonic acid pathway: A review. J. Adv. Res. 2015, 6, 17-33. [CrossRef] [PubMed]

168. Moon, K.; Lee, S.; Cha, J. Bacillus subtilis Fermentation of Malva verticillata Leaves Enhances Antioxidant Activity and Osteoblast Differentiation. Foods 2020, 9, 671. [CrossRef]

169. Liang, Y.Y.; Wan, X.H.; Niu, F.J.; Xie, S.M.; Guo, H.; Yang, Y.Y.; Guo, L.Y.; Zhou, C.Z. Salvia plebeia R. Br.: An overview about its traditional uses, chemical constituents, pharmacology and modern applications. Biomed. Pharm. 2020, 121, 109589. [CrossRef] [PubMed]

170. Zou, Y.H.; Zhao, L.; Xu, Y.K.; Bao, J.M.; Liu, X.; Zhang, J.S.; Li, W.; Ahmed, A.; Yin, S.; Tang, G.H. Anti-inflammatory sesquiterpenoids from the Traditional Chinese Medicine Salvia plebeia: Regulates pro-inflammatory mediators through inhibition of NF-kappaB and Erk1/2 signaling pathways in LPS-induced Raw264.7 cells. J. Ethnopharmacol. 2018, 210, 95-106. [CrossRef]

171. Jang, H.H.; Cho, S.Y.; Kim, M.J.; Kim, J.B.; Lee, S.H.; Lee, M.Y.; Lee, Y.M. Anti-inflammatory effects of Salvia plebeia R. Br extract in vitro and in ovalbumin-induced mouse model. Biol. Res. 2016, 49, 41. [CrossRef] [PubMed]

172. Bang, S.; Li, W.; Ha, T.K.Q.; Lee, C.; Oh, W.K.; Shim, S.H. Anti-influenza effect of the major flavonoids from Salvia plebeia R.Br. via inhibition of influenza H1N1 virus neuraminidase. Nat. Prod. Res. 2018, 32, 1224-1228. [CrossRef]

173. Hwang, E.K.; Gong, Y.G.; Park, C.S. Cultivation of a brown alga, Undariopsis peterseniana (Kjellman) Miyabe and Okamura, as a warm-temperature species by artificial seed production in Korea. J. Appl. Phycol. 2011, 23, 449-455. [CrossRef]

174. Cho, M.; Yoon, S.J.; Kim, Y.-B. The nutritional composition and antioxidant activity from Undariopsis peterseniana. Ocean. Polar Res. 2013, 35, 273-280. [CrossRef]

175. Lee, J.H.; Ko, J.Y.; Kim, E.A.; Hwang, E.K.; Park, C.S.; Lee, J.S.; Kim, C.Y.; Lee, H.S.; Kang, H.K.; Cha, S.H.; et al. Identification and large isolation of an anti-inflammatory compound from an edible brown seaweed, Undariopsis peterseniana, and evaluation on its anti-inflammatory effect in in vitro and in vivo zebrafish. J. Appl. Phycol. 2017, 29, 1587-1596. [CrossRef] 
176. Kang, M.C.; Ham, Y.M.; Heo, S.J.; Yoon, S.A.; Cho, S.H.; Kwon, S.H.; Jeong, M.S.; Jeon, Y.J.; Sanjeewa, K.; Yoon, W.J.; et al. Anti-inflammation effects of 8-oxo-9-octadecenoic acid isolated from Undaria peterseniana in lipopolysaccharide-stimulated macrophage cells. EXCLI J. 2018, 17, 775-783. [CrossRef] [PubMed]

177. Urysiak-Czubatka, I.; Kmiec, M.L.; Broniarczyk-Dyla, G. Assessment of the usefulness of dihydrotestosterone in the diagnostics of patients with androgenetic alopecia. Postepy Dermatol. Alergol. 2014, 31, 207-215. [CrossRef] [PubMed]

178. Adil, A.; Godwin, M. The effectiveness of treatments for androgenetic alopecia: A systematic review and meta-analysis. J. Am. Acad. Dermatol. 2017, 77, 136-141.e135. [CrossRef]

179. Dinh, Q.Q.; Sinclair, R. Female pattern hair loss: Current treatment concepts. Clin. Interv. Aging 2007, 2, 189. [PubMed]

180. Said, M.A.; Mehta, A. The Impact of $5 \alpha$-Reductase inhibitor use for male pattern hair loss on men's health. Curr. Urol. Rep. 2018, 19, 65. [CrossRef]

181. Yu, W.; Zha, W.; Guo, S.; Cheng, H.; Wu, J.; Liu, C. Flos Puerariae extract prevents myocardial apoptosis via attenuation oxidative stress in streptozotocin-induced diabetic mice. PLoS ONE 2014, 9, e98044. [CrossRef] [PubMed]

182. Lertpatipanpong, P.; Janpaijit, S.; Park, E.Y.; Kim, C.T.; Baek, S.J. Potential Anti-Diabetic Activity of Pueraria lobata Flower (Flos Puerariae) Extracts. Molecules 2020, 25, 3970. [CrossRef] [PubMed]

183. Han, Y.O.; Han, M.J.; Park, S.H.; Kim, D.H. Protective effects of kakkalide from Flos puerariae on ethanol-induced lethality and hepatic injury are dependent on its biotransformation by human intestinal microflora. J. Pharm. Sci. 2003, 93, 331-336. [CrossRef]

184. Zhuang, B.; Bi, Z.M.; Wang, Z.Y.; Duan, L.; Lai, C.J.; Liu, E.H. Chemical profiling and quantitation of bioactive compounds in Platycladi Cacumen by UPLC-Q-TOF-MS/MS and UPLC-DAD. J. Pharm. Biomed. Anal. 2018, 154, 207-215. [CrossRef] [PubMed]

185. Zhang, Y.; Chen, S.; Qu, F.; Su, G.; Zhao, Y. In vivo and in vitro evaluation of hair growth potential of Cacumen Platycladi, and GC-MS analysis of the active constituents of volatile oil. J Ethnopharmacol. 2019, 238, 111835. [CrossRef]

186. Pan, J.; Zheng, W.; Pang, X.; Zhang, J.; Chen, X.; Yuan, M.; Yu, K.; Guo, B.; Ma, B. Comprehensive Investigation on Ginsenosides in Different Parts of a Garden-Cultivated Ginseng Root and Rhizome. Molecules 2021, 26. [CrossRef]

187. Wang, H.P.; Zhang, Y.B.; Yang, X.W.; Zhao, D.Q.; Wang, Y.P. Rapid characterization of ginsenosides in the roots and rhizomes of Panax ginseng by UPLC-DAD-QTOF-MS/MS and simultaneous determination of 19 ginsenosides by HPLC-ESI-MS. J. Ginseng Res. 2016, 40, 382-394. [CrossRef]

188. Kim, S.; Oh, M.H.; Kim, B.S.; Kim, W.I.; Cho, H.S.; Park, B.Y.; Park, C.; Shin, G.W.; Kwon, J. Upregulation of heme oxygenase-1 by ginsenoside Ro attenuates lipopolysaccharide-induced inflammation in macrophage cells. J. Ginseng Res. 2015, 39, 365-370. [CrossRef] [PubMed]

189. Matsuda, H.; Samukawa, K.; Kubo, M. Anti-inflammatory activity of ginsenoside ro. Planta Med. 1990, 56, 19-23. [CrossRef]

190. Kang, H.J.; Oh, Y.; Lee, S.; Ryu, I.W.; Kim, K.; Lim, C.J. Antioxidative properties of ginsenoside Ro against UV-B-induced oxidative stress in human dermal fibroblasts. Biosci. Biotechnol. Biochem. 2015, 79, 2018-2021. [CrossRef] [PubMed]

191. Jiang, L.S.; Li, W.; Zhuang, T.X.; Yu, J.J.; Sun, S.; Ju, Z.C.; Wang, Z.T.; Ding, L.L.; Yang, L. Ginsenoside Ro Ameliorates High-Fat Diet-Induced Obesity and Insulin Resistance in Mice via Activation of the G Protein-Coupled Bile Acid Receptor 5 Pathway. J. Pharm. Exp. Ther. 2021, 377, 441-451. [CrossRef] [PubMed]

192. Zhang, L.; Dong, R.; Wang, Y.; Wang, L.; Zhou, T.; Jia, D.; Meng, Z. The anti-breast cancer property of physcion via oxidative stress-mediated mitochondrial apoptosis and immune response. Pharm. Biol. 2021, 59, 303-310. [CrossRef]

193. Trybus, W.; Krol, T.; Trybus, E.; Stachurska, A. Physcion Induces Potential Anticancer Effects in Cervical Cancer Cells. Cells 2021, 10, 2029. [CrossRef] [PubMed]

194. Wang, W.; Wu, N.; Zu, Y.; Fu, Y. Antioxidative activity of Rosmarinus officinalis L. essential oil compared to its main components. Food Chem. 2008, 108, 1019-1022. [CrossRef] [PubMed]

195. Oluwatuyi, M.; Kaatz, G.W.; Gibbons, S. Antibacterial and resistance modifying activity of Rosmarinus officinalis. Phytochemistry 2004, 65, 3249-3254. [CrossRef] [PubMed]

196. Pérez-Sánchez, A.; Barrajón-Catalán, E.; Ruiz-Torres, V.; Agulló-Chazarra, L.; Herranz-López, M.; Valdés, A.; Cifuentes, A.; Micol, V. Rosemary (Rosmarinus officinalis) extract causes ROS-induced necrotic cell death and inhibits tumor growth in vivo. Sci. Rep. 2019, 9, 808. [CrossRef] [PubMed]

197. Sharaf, M.; El-Ansari, M.A.; Saleh, N.A. New flavonoids from Avicennia marina. Fitoterapia 2000, 71, 274-277. [CrossRef]

198. Heo, S.-J.; Park, E.-J.; Lee, K.-W.; Jeon, Y.-J. Antioxidant activities of enzymatic extracts from brown seaweeds. Bioresour. Technol. 2005, 96, 1613-1623. [CrossRef]

199. Wijesinghe, W.; Jeon, Y.-J. Exploiting biological activities of brown seaweed Ecklonia cava for potential industrial applications: A review. Int. J. Food Sci. Nutr. 2012, 63, 225-235. [CrossRef]

200. Kang, J.-I.; Kim, S.-C.; Kim, M.-K.; Boo, H.-J.; Jeon, Y.-J.; Koh, Y.-S.; Yoo, E.-S.; Kang, S.-M.; Kang, H.-K. Effect of Dieckol, a component of Ecklonia cava, on the promotion of hair growth. Int. J. Mol. Sci. 2012, 13, 6407-6423. [CrossRef]

201. Abe, Y.; Tanaka, N. Roles of the Hedgehog Signaling Pathway in Epidermal and Hair Follicle Development, Homeostasis, and Cancer. J. Dev. Biol. 2017, 5. [CrossRef]

202. Bitgood, M.J.; McMahon, A.P. Hedgehog and Bmp genes are coexpressed at many diverse sites of cell-cell interaction in the mouse embryo. Dev. Biol. 1995, 172, 126-138. [CrossRef] [PubMed]

203. St-Jacques, B.; Dassule, H.R.; Karavanova, I.; Botchkarev, V.A.; Li, J.; Danielian, P.S.; McMahon, J.A.; Lewis, P.M.; Paus, R.; McMahon, A.P. Sonic hedgehog signaling is essential for hair development. Curr. Biol. 1998, 8, 1058-1068. [CrossRef] 
204. Chakrawarti, L.; Agrawal, R.; Dang, S.; Gupta, S.; Gabrani, R. Therapeutic effects of EGCG: A patent review. Expert Opin. Pat. 2016, 26, 907-916. [CrossRef] [PubMed]

205. Patel, S.; Sharma, V.; Chauhan, N.S.; Thakur, M.; Dixit, V.K. Hair growth: Focus on herbal therapeutic agent. Curr. Drug Discov. Technol. 2015, 12, 21-42. [CrossRef] [PubMed]

206. Saraste, A.; Pulkki, K. Morphologic and biochemical hallmarks of apoptosis. Cardiovasc Res. 2000, 45, 528-537. [CrossRef]

207. Fulda, S.; Debatin, K.M. Extrinsic versus intrinsic apoptosis pathways in anticancer chemotherapy. Oncogene 2006, $25,4798-4811$. [CrossRef] [PubMed]

208. Knudson, C.M.; Korsmeyer, S.J. Bcl-2 and Bax function independently to regulate cell death. Nat. Genet. 1997, 16, 358-363. [CrossRef]

209. Stenn, K.S.; Paus, R. Controls of hair follicle cycling. Physiol. Rev. 2001, 81, 449-494. [CrossRef]

210. Seiberg, M.; Marthinuss, J.; Stenn, K.S. Changes in expression of apoptosis-associated genes in skin mark early catagen. J. Investig. Dermatol. 1995, 104, 78-82. [CrossRef]

211. Giacomini, F.; Starace, M.; Tosti, A. Short anagen syndrome. Pediatric Dermatol. 2011, 28, 133-134. [CrossRef]

212. Murugusundram, S. Serenoa repens: Does it have any role in the management of androgenetic alopecia? J. Cutan. Aesthetic Surg. 2009, 2, 31. [CrossRef] [PubMed]

213. Xu, X.; Lyle, S.; Liu, Y.; Solky, B.; Cotsarelis, G. Differential expression of cyclin D1 in the human hair follicle. Am. J. Pathol. 2003, 163, 969-978. [CrossRef]

214. Purba, T.S.; Brunken, L.; Hawkshaw, N.J.; Peake, M.; Hardman, J.; Paus, R. A primer for studying cell cycle dynamics of the human hair follicle. Exp. Dermatol. 2016, 25, 663-668. [CrossRef]

215. Whittaker, S.R.; Mallinger, A.; Workman, P.; Clarke, P.A. Inhibitors of cyclin-dependent kinases as cancer therapeutics. Pharm. Ther. 2017, 173, 83-105. [CrossRef] [PubMed] 